Hispania Sacra, LXII

126, julio-diciembre 2010, 457-489, ISSN: 0018-215-X

\title{
LOS SANTOS Y EL IMAGINARIO URBANO EN LOS DISCURSOS HISTORIOGRÁFICOS: ANDALUCÍA SIGLOS XIII-XVII
}

\author{
POR \\ Andrea Mariana NaVARro \\ Universidad Nacional de Tucumán-Argentina
}

\begin{abstract}
RESUMEN
La historiografía nos ofrece una extensa relación sobre las imágenes, reliquias y milagros que garantizaban la «eterna presencia» de los santos en las comunidades andaluzas. Tal creencia, además de expresar las sensibilidades colectivas y la religiosidad popular, constituyó un tema clave que puede ser interpretado como producto de una construcción ideológica, forjada por un discurso, una narración de eruditos laicos y eclesiásticos que, impulsados por sentimientos de orgullo patrio y localista, quisieron exaltar el honor, el ennoblecimiento y engrandecimiento urbano.
\end{abstract}

PALABRAS CLAVE: Santos, imagines, reliquias religiosidad, popular, Andalucía.

\section{SAINTS AND THE URBAN IMAGINARY IN HISTORIOGRAPHIC DISCOURSE: ANDALUSIA 13 TH AND 14 TH CENTURIES}

\section{ABSTRACT}

Historiography offers us and extent relation about images, relics and miracles that guaranteed the «eternal presence» of saints in Andalusian communities. Such belief, apart from expressing collective sensibility and popular religiousness, constituted a key subject that can be interpreted as the product of an ideological construction. This construction was forged by the discourse and the accounts of learned laymen and ecclesiastics who led by a sense of patriotic pride intended to highlight honor and urban dignity.

KEY WORDS: Saints, images, relics, popular religiousness, Andalusia

Recibido/Received 03-03-2009

Aceptado/Accepted 18-05-2009 
Durante los siglos XVI y XVII se desarrollaron en Europa sentimientos «nacionalistas» que tuvieron una importante dimensión religiosa. En esa época en que la religiosidad comenzó a discurrir por cauces distintos en la comunidad de creyentes católicos, la historiografía española se propuso demostrar los grandes contrastes de España con otros Estados Modernos. Para ello puso de relieve peculiaridades regionales y definió sus identidades, exponiendo, en cada caso, particularidades relacionadas con la defensa del dogma y la promoción de sus santos y religiosos, así como de sus historias eclesiásticas. Los autores, cronistas, nobles y clérigos dominicos, franciscanos y jesuitas, conscientes de formar parte de una entidad política, civil, moral, religiosa y espiritual con peculiares características, indagaron en la historia aquello que los hacía «únicos y distintos». Difundieron la imagen de España como paradigma de República Cristia$n a$, idea que tenía una larga evolución en el pensamiento político y teológico, que contaba con referentes en concepciones clásicas y cristianas y se acoplaba a los intereses nacionales de la Iglesia y la Corona española.

Esta representación ideal exaltó valores de la nación articulados en torno a dos cuestiones básicas: la misión evangélica, militante, civilizadora y su defensa de la fe católica frente a otras confesiones. La mejor forma de demostrar que España participaba plenamente de esos principios fue a través de la construcción teórica de las «ciudades cristianas», enmarcada en una concepción político-religiosa llevada a cabo por la Reconquista y desarrollada en los siglos XVI y XVII en el contexto de las luchas religiosas y políticas europeas, de conquista y evangelización de las nuevas tierras en América. ${ }^{1}$ En ese marco, la historiografía consideró a las ciudades andaluzas como modelos religiosos y difundió, como ya lo había hecho en la Edad Media, la idea providencialista de sus historias.

Sus señas de identidad quedaron precisadas en la exposición acerca de la santidad, religiosidad, virtudes piadosas y caritativas de sus «hijos y ciudadanos», componiéndose con ellas un conjunto de sensibilidades, actitudes y mentalidades que exaltaban a las ciudades y a sus comunidades. Tales conceptos constituyeron las bases de los discursos de historias generales de España, historias locales urbanas e historias eclesiásticas, en muchas de las cuales pueden reconocerse los tópicos del género de las laudes civitatis. ${ }^{2}$

\footnotetext{
${ }^{1}$ Santiago QuESADA, La idea de ciudad en la cultura hispana de la Edad Moderna, Universidad de Barcelona, 1992.

${ }^{2} \mathrm{El}$ fuerte sentido de comunidad entre los habitantes de las ciudades -en gran parte heredado de la Edad Media- se desarrolló en la Edad Moderna dando paso a manifestaciones de orgullo localista reflejadas en textos de carácter encomiástico, panegírico y propagandístico, orientados a exaltar un profundo sentimiento patriótico que tendía a potenciar la valoración de los reinos, villas y ciudades de España. La estructura y contenido de estas obras se organizó en función de un esquema teórico preconcebido: presentaron arquetipos, representaciones ideales de ciudades y de sus sociedades, que encarnaban virtudes temporales y espirituales, basadas en la pertenencia a la comunidad eminentemen-
}

Hispania Sacra, LXII

126, julio-diciembre 2010, 457-489, ISSN: 0018-215-X 
Para los autores, nada honraba más a la «patria» que sus «insignes varones y ciudadanos» que con sus vidas y obras propiciaron la fama de las ciudades por medio de las armas, las letras y las ciencias. ${ }^{3}$ Sin embargo, la representación de España y sus ciudades requería que los promotores de la República Cristiana exaltaran cualidades religiosas de sus sociedades y, la mejor forma de llevarla a cabo fue a través de sus santos y mártires, que por su número y ejemplos, convertían a las ciudades andaluzas en ejes centrales de la geografía de la santidad hispánica.

En este artículo, veremos a lo largo de sus páginas, de qué modo las fuentes historiográficas demostraron los vínculos que unían a las ciudades con sus santos, sus principales símbolos de identidad, sus defensores, protectores y eficaces «muros espirituales de sus comunidades». Presentamos aquí cuatro modalidades de las que se valieron para sacralizar y «ennoblecer» el espacio urbano por medio de los santos: la clarificación de la noción de pertenencia, la posesión y traslatio de reliquias-santas, la inventio o hallazgo de imágenes y las apariciones desde el «más allá».

Como si reprodujeran a la Civitas Dei agustiniana en la tierra andaluza, o Dios hubiera colocado en ella la «Jerusalén triunfante», los escritores se sirvieron de estas fórmulas para mostrar la «presencia permanente» de la Virgen y los santos en sus ciudades, tema que consideramos, fue central en las expresiones del orgullo localista y una cuestión clave para probar la seguridad física y espiritual que gozaban sus sociedades. ${ }^{4}$

te cristiana, religiosa y devota; con orígenes remotos que avalaban su antigüedad; excelencias y grandezas provenientes de su tierra, de sus habitantes y de la fidelidad y lealtad demostradas a los monarcas.

${ }^{3}$ Las historias que estudiamos tomaron estos modelos de las preceptivas de escritores clásicos -Nepote, Plutarco, Valerio Máximo- y medievales -Fernán Pérez de Guzmán y Hernando del Pulgarque centraron su atención en dos virtudes: fortitudo y sapientia.

${ }^{4}$ Precisamente, dentro de este marco expuesto, una de las fuentes claves de estas obras fueron las hagiografías. Sin duda, fueron uno de los medios fundamentales para promover el culto a los santos y favorecer su difusión y veneración. Redactadas y codificadas por clérigos y órdenes religiosas, esos textos respondían a estrategias pastorales y espirituales que potenciaban y exaltaban virtudes, comportamientos y valores ejemplarizantes. Ciertamente, la inclusión de martirologios y pasionarios tuvo una intención pedagógica-edificante que se cumplía instruyendo a los fieles y dando a conocer las vidas de los santos y mártires con el relato de sus gestas, actuaciones épicas y heroicidades -según modelos de santidad elaborados por la jerarquía eclesiástica- que podían incitar a ser imitados por los ciudadanos. Por otra parte, la Iglesia quiso mantener vivo el recuerdo de sus «héroes cristianos», para ello sacralizó el año organizando detalladamente el calendario de celebraciones, consignando las fechas de sus festividades. También dio legitimidad a la veneración de las reliquias incluyendo noticias sobre su traslatio, sobre inventio de imágenes o relatos sobre apariciones, revelaciones de la Virgen o de los santos, visiones del clero, de ciudadanos y de aldeanos. Todas ellas permitieron promocionar y prestigiar los lugares de culto (loca sanctorum) que se honraban mediante la construcción de monumentos, iglesias, ermitas, humilladeros, dando cuenta así de la multiplicación de los espacios sagrados. 
EL «ENNOBLECIMIENTO» DE LAS CIUDADES A TRAVÉS DE SUS SANTOS

La imagen de una nación con sus santos y mártires como sus más apreciables símbolos de identidad, fue el fundamento esencial en el que se basó la historiografía para avalar el prestigio de España, presentándola como uno de los máximos prototipos de la cristiandad, digna de gloria porque, con su «presencia», santos y mártires la «honraban, engrandecían y ennoblecían en el cielo y en la tierra».

Muchas ciudades de España se consideraron tan insignes como las grandes urbes de la cristiandad, Jerusalén y Roma, ambas centros de peregrinación y «madres de numerosos santos y mártires». En este sentido, las historias generales, locales y eclesiásticas subrayaron la riqueza espiritual y religiosa de España y sus ciudades, por ser un «espacio privilegiado y de los más pródigos en santidad en Europa Occidental».5

Resulta ilustrativa la imagen que ofrece Fray Juan de Marieta, de la Orden de Santo Domingo (1594) porque, en tiempos en que España era considerada la nación más poderosa del orbe debido al descubrimiento de América y a las riquezas que de allí llegaban, equiparaba los numerosos santos que poseía la nación conquistadora con los tesoros en oro y plata, afirmando «sin contradicción tiene ventaja a las mejores tierras del mundo». 6

Al recorrer los textos, se percibe la valoración de los santos por parte de los escritores que componen las historias de las ciudades andaluzas. Se advierte cómo reafirmaron la idea sostenida por la Iglesia: los santos elevaban, exaltaban, dignificaban y ennoblecían a «sus patrias»; avivaban el prestigio de los centros religiosos, iglesias, conventos, monasterios, fundados por ellos, puestos bajo su advocación o donde fueron sepultados. ${ }^{7}$ En ese sentido, Andalucía

\footnotetext{
5 Ambrosio Morales, Crónica General de España, Alcalá de Henares, 1574, Libro VIII, cap. XLVII, 183v; Diego PÉREZ DE MESA, Primera y segunda parte de las grandezas y cosas notables de Espa$\tilde{n} a$, Sevilla, 1595, cap. XII, 11.

${ }^{6}$ Fray Juan de MARIETA, Historia Eclesiástica de los santos de España, primera, segunda, tercera y cuarta parte, Cuenca, 1594, Libro I, cap. XII, 10v.

7 Con respecto a Córdoba, se señala: «En la iglesia católica ha querido Nuestro Señor no se halle ciudad que no tenga sus santos patronos que la defiendan y amparen con su intercesión... son las ricas alhajas que enriquecen y ennoblecen la ciudad de Córdoba regándola toda con su sangre, y esta pide y da voces por su intercesión; no la niegan las gloriosas almas alcanzando de Dios en el cielo singulares dones y mercedes para su patria.», en Andrés de Morales y PADILla, Historia General de Córdoba, 1620, Adelma Cano Fernández, y Vicente Millán Torres, (Eds), Ayuntamiento de Córdoba, Exma. Diputación de Córdoba, 2005, Libro IV, cap. I, 396 y 393. También Sevilla exaltó la relación con sus santos: "Casi todas las iglesias de España han publicado las historias de los santos de sus diócesis, la de Sevilla, tan ilustre ciudad en dignidad, antigüedad y preeminencias... justo era sacarle a la luz del mundo, luz de santos y tan superiores. Con esta obra sirve a Sevilla, a quien reconoce por madre, sírvele mi afecto en engrandecer a estos santos y en ellos a sus patrias.», Antonio QUINTANADUEÑAS, San-
}

Hispania Sacra, LXII

126, julio-diciembre 2010, 457-489, ISSN: 0018-215-X 
-que conservó con celo la fe católica frente al paganismo, el arrianismo y el Islam- fue merecedora de ser considerada «tierra fructífera en modelos heroicos de santidad», rica en la posesión de «tesoros santos», por un sin número de santos y reliquias en torno a los cuales se organizaron la religiosidad, el culto y las devociones de sus pobladores. ${ }^{8}$ Todo este discurso se alimentó de las hagiografías que contenían las historias de vida, virtudes y milagros de los santos, género que tuvo gran difusión en los primeros tiempos del cristianismo y al-

tos de la ciudad de Sevilla y su arçobispado: fiestas que su santa Iglesia Metropolitana celebra al Ilustrísimo Señor Deán y Cabildo de la misma Santa Iglesia, Sevilla, 1637. Por su parte, el cronista mayor de las Indias y de los Reinos de Castilla, que escribió una obra dedicada al rey Felipe IV manifestaba: "Quiero llamar Tierra Santa a la del Archiprestazgo de Andújar porque en lugar de frutos lleva y produce mártires y confesores que honran al cielo», las mismas «maravillas»-según este autor- había obrado Dios en Écija, ciudad que resplandecía también en santidad, Gil GonZÁLEZ DávILA, Teatro Eclesiástico de las Iglesias Metropolitanas y Catedrales de los Reynos de las dos Castillas: vidas de sus arzobispos y obispos, y cosas memorables de sus sedes. T. I que contiene las Iglesias de Santiago, Sigüenza, Jaén, Murcia, León, Cuenca, Segovia y Valladolid, Madrid, 1645, 234 y T. II que contiene las Iglesias de Sevilla, Palencia, Ávila, Zamora, Coria, Calahorra y Plasencia, Madrid, 1647, 71. Y en la crónica compuesta por un religioso de la Compañía de Jesús, dedicada a su ciudad, Baeza se expresa: «...viene bien hacer un breve catálogo de esta piedras preciosas (los santos) que exceden en tercio y quinto a el oro y la plata, y son de inestimable valor, por ser capaçes de ver a Dios y ser colocados en aquella çiudad de Jerusalén triunfante», en P. Francisco Torres, Historia de Baeza, Estudio y edición de José Rodríguez Molina, Diputación Provincial de Jaén, Exmo. Ayuntamiento de Baeza, 1999, cap. XIII, 159.

${ }^{8}$ Véase las siguientes obras generales de referencia. Pedro CAstillo Maldonado, «Cristianos y hagiógrafos: estudios de las propuestas de excelencia cristiana en la Antigüedad Tardía», Signifer Libros, 2002; Los mártires hispanorromanos y su culto en la Antigüedad Tardía, Universidad de Granada, 1999 y La primera cristianización de Jaén. Historia eclesiástica siglos IV-VI, Universidad de Jaén, 2005; Ariel GUIANCE, «Nacionalismos hagiográficos: la idea de España en la hagiografía altomedieval de España», Temas Medievales 11, Bs. As., (2002-2003); Javier PÉREz-EmBiD WAMBA, Hagiología y sociedad en la España Medieval: Castilla y León (siglos XI-XIII), Universidad de Huelva, 2002; Alfonso Franco Silva, «La religiosidad popular en la Baja Edad Media», Actas de los VII Encuentros de Historia y Arqueología. Gremios, Hermandades y Cofradías. Una aproximación científica al asociacionismo profesional en la Historia de Andalucía, San Fernando, 1991; O. GIORDANo, Religiosidad popular en la Alta Edad Media, Madrid, 1983; Manuel PEÑA DíAZ, «Caro Baroja y la religiosidad en la España del Siglo de Oro», Historia Social N $N^{\circ} 55$, (2006). Sobre Andalucía específicamente: Adela MuÑOZ FERNÁNDEZ, «Cultos, devociones y advocaciones religiosas en los orígenes de la organización eclesiástica cordobesa, (siglos XIII-XIV),» en CABRERA, Emilio (coord), Andalucía entre Oriente y Occidente (1236-1492), Actas del V Coloquio Internacional de Historia Medieval de Andalucía, Exma. Diputación de Córdoba, 1988; Rafael Rodríguez-MoÑIno SoRIANo, Aproximación a la Historia Eclesiástica de la ciudad de Baeza (Jaén). Del esplendor renacentista y barroco a la crisis liberal del siglo XIX, Diputación Provincial de Jaén, Instituto de Estudios Giennenses, 2000; José RoDRÍGUEZ MolINA, El Obispado de Jaén-Baeza. Organización y economía diocesana (siglos XIII-XVI), Diputación Provincial de Jaén, Instituto de Cultura, 1986; Iluminado SANZ SANCHo, Geografía del Obispado de Córdoba en la Baja Edad Media, Polifemo, Universidad Autónoma, Madrid, 1995 y La Iglesia y el Obispado de Córdoba en la Baja Edad Media (1236-1426), Universidad Complutense, Madrid, 1989; José SÁnchez Herrero, Historia de las diócesis españolas. Iglesias de Sevilla, Huelva, Jerez, Cádiz y Ceuta, BAC, Córdoba, 2002. 
canzó nuevo impulso y desarrollo en la cultura del Renacimiento y del Barroco español. ${ }^{9}$

Cabe señalar que esta relación de los santos con las ciudades y su significación no era nueva. Las alabanzas, a la que hacemos referencia, tenían larga data y lejanas raíces, por tanto, no hicieron más que dar continuidad a las que estaban ya presentes en el Peristephanon, uno de los documentos más antiguos de la literatura hagiográfica peninsular que compiló himnos o cantos dedicados a las gestas de los santos mártires hispanorromanos. Redactado entre fines del siglo IV y principios del siglo V por Aurelio Prudencio, podríamos considerarlo un antecedente o modelo para los escritores modernos, pues fue tal vez la obra más ilustrativa por la enumeración hagiográfica que presenta y por el prestigio que los santos, vírgenes y mártires le conferían a las ciudades de la península ibérica a través de la posesión de numerosas reliquias. ${ }^{10}$

De la misma manera, las historias generales, las historias urbanas y eclesiásticas de Andalucía han puesto de relieve los innumerables santos y mártires que ha tenido la región y sus ciudades. La producción historiográfica no ha hecho más que ratificar «la grandeza de Dios que las ha elegido como patrias de los

${ }^{9}$ En los siglos XVI y XVII, este género tuvo gran demanda en la sociedad andaluza publicándose los libros en las imprentas de Sevilla, Córdoba y Baeza y difundiéndose en textos, pliegos sueltos, coplas, poemas y romances. Su contenido religioso iba dirigido a un amplio abanico de lectores, pero también podía ser escuchado en el ámbito doméstico de la clase noble y la oligarquía urbana, o en el ámbito eclesiástico de conventos y monasterios que encontraban en sus páginas lecciones sobre virtudes, contenidos morales y preceptos cristianos. Marc ViTse, (coord), Homenaje a Henri Guerreiro. La Hagiografía entre la historia y literatura en la España de la Edad Media y del Siglo de Oro, Iberoamericana, 2006; Fernando BAÑos VALLEJo, Las vidas de los santos en la literatura medieval española, Laverinto, 2003; María Ángeles GARCía DE LA BorBOLLA, «La hagiografía medieval. Una particular historiografía. Balance del caso hispano», Hispania Sacra, LI/104 (julio-diciembre1999) 687-702

${ }^{10}$ La importancia del Peristephanon radica en que se compuso en la época de conformación y desarrollo del culto martirial en Hispania (siglos IV y V d.C.) siendo así la fuente principal en la que se basó el martirologio hispánico. A partir de esa época floreció la producción literaria basada en tradiciones orales y escritas que tenían como fin glorificar a los santos y mártires, entre la que cabe destacar la tradición martirial del siglo IX reflejada por los principales exponentes de ese fenómeno religioso, Eulogio y Alvaro de Córdoba, en Memoriale Sanctorum, Documentum Martyriale, Apologeticus Martyrum e Indiculus luminosus, respectivamente. Citamos El Peristephanon II porque en él se advierte un intento del autor de hacer que Hispania emule a Jerusalén y a Roma, imitándolas y aventajándolas, al presentar sus numerosos ejemplos de santidad, ya que estas grandes urbes de la cristiandad estaban llenas de mártires enterrados, y su suelo florecía rico en sepulcros de santos, tal como se propuso la historiografía moderna que estudiamos. Asimismo, Prudencio cantó en El Peristephanon IV a una serie de ciudades principales españolas que en cortejo triunfante presentarían en la Parusía sus mártires, a modo de méritos, de dádivas, de ofrendas sagradas, cuando Dios retorne el día de Juicio Final. Y aunque en sus versos, había alusiones breves de los santos-mártires de la región Bética, se advierte claramente que la atención del autor se centró en los santos de su ciudad natal, Calahorra y en los de la región Terraconense, especialmente Zaragoza, la ciudad que tenía «la más copiosa comitiva de mártires», en Obras completas de Aurelio Prudencio, BAC, Madrid, 1950, Himno IV, 541-543.

Hispania Sacra, LXII

126, julio-diciembre 2010, 457-489, ISSN: 0018-215-X 
santos», tierra que protegen y en la que ejercen su patronato. Así encontramos en sus textos discursos de alabanza que presentan un extenso registro de adjetivos calificativos en los que se advierte cómo se definen las ciudades andaluzas desde sus santos. Unas y otras proclamaban el título de «Cristianísima», «Grande», «Madre de numerosos santos», «ejemplo de santidad», «Ilustrísima», «Piísima», «Religiosísima», «Misericordiosa», «Dignísima», «Bienaventurada», «Precursora de la Religión Cristiana», «Honrada», «Retrato del Cielo». En los discursos, toda esta enumeración refleja imágenes ideales que proceden de la noción de lo sagrado que expresa la idea de separación, segregación y distinción, que las singulariza a ellas y a sus comunidades.

Los textos afirmaron así un sistema de relaciones con lo divino y de éste con su territorio. Por un lado, la sacralización, a través de las cuatro modalidades que trataremos a continuación, le otorgó a las ciudades un sentido simbólico, atribuyendo a una realidad ordinaria una significación religiosa. Por otro, puso de relieve que sus comunidades vivenciaron lo sagrado, siendo protagonistas de milagros. ${ }^{11}$

\section{LA NOCIÓN DE PERTENENCIA DE LOS SANTOS A LAS CIUDADES}

¿Cómo los itinerarios de los santos y mártires contribuyeron, según los discursos historiográficos, a la sacralización de las ciudades andaluzas y al trasvase de advocaciones? Generalmente los lugares en los que los santos abandonaban el mundo terreno para pasar a la gloria eterna tras su muerte o martirio, fueron centros fundamentales del culto. La Iglesia y las prácticas religiosas populares diversificaron y multiplicaron las posibilidades elevando el status de los lugares que conservaban la presencia tangible de los santos: donde se encontraban sus reliquias, donde habían vivido o realizaron milagros. La Iglesia los integró tomando el ejemplo de la significación de Belén «como patria de Cristo por su nacimiento», de Nazaret como su «lugar de residencia y predicación»y Jerusalén como «lugar de su muerte», para establecer la relación de los santos y mártires con las ciudades.

Como sabemos, para el hombre de fe, los lugares y los tiempos no son todos iguales e igualmente significativos. Algunos tienen una capacidad especial de evocación religiosa por ser signos de irrupción de lo divino en la vida humana o gozar de una relación con ella y, de alguna forma, participar de su trascenden-

11 Jean-Claude SCHMITT, «La noción de lo sagrado y su aplicación a la historia del cristianismo medieval», Temas Medievales 3, Bs. As., (1993); C. Álvarez Santalo, Ma . Buxo Rey y S. Rodríguez BECERRA, (coords.), La religiosidad popular III, Hermandades, romerías y santuarios, Anthropos, Barcelona, (2003). 
cia. En ese sentido, hay que señalar, en primer término, que las historias presentaron una relación pormenorizada sobre la topografía religiosa de sus ciudades.

Por ejemplo, la catedral de Sevilla reunió gran cantidad de reliquias santas, entre ellas el cuerpo de Fernando III, conquistador y «refundador» de la ciudad, «modelo de rey y caballero cristiano», que al elegirla para su sepulcro honró con numerosos privilegios a la Iglesia de Santa María y a la ciudad antes de ser canonizado en 1671. Asimismo, las patronas de la ciudad, Santas Justa y Rufina, convirtieron a muchos de los espacios urbanos en los principales lugares píos: el prado llamado de Santa Justa, -en las afueras, cerca del muro- donde se cree que pudo haber estado su casa o fue sepultada; el monasterio de la Santísima Trinidad -donde se situó la cárcel en la que estuvieron presas las santas-; un pozo de agua usado con gran devoción para curar enfermedades -donde se dice que fue echada una de ellas-; un lugar cerca del río -donde ambas vendían sus vasijas- y numerosos templos. ${ }^{12}$

También Córdoba presentó una multiplicidad de espacios sacralizados en virtud de la «presencia» de sus santos: la Fuensanta y una ermita donde se cree que reposaban los santos Acisclo y Victoria -frente a la puerta del Colodro-; el monasterio de frailes dominicos donde la tradición cuenta que estaban los cuerpos de los hermanos -junto a la puerta que conducía a la villa de Martos-; la parroquia de San Miguel labrada en memoria de San Zoilo; una casa antigua que gozó de mucha reverencia y devoción porque se cree que este santo fue allí martirizado y un pozo de agua en el que posiblemente sus restos fueron echados, donde la gente acudía para calmar y sanar los dolores de riñón y de ijada; el monasterio de San Pablo, las Iglesias de San Pedro, San Martín, Santa Marina, San Andrés y San Nicolás enriquecidas con reliquias de santos y mártires; el alcázar real donde los santos mencionados por San Eulogio estuvieron prisioneros y fueron sentenciados; el río Guadalquivir cuyas aguas se cree que tenían propiedades taumatúrgicas porque allí fueron arrojados muchos cuerpos de mártires; el Campo de la Verdad donde muchos mártires perecieron y las puertas de Gallegos, de Hierro y de Córdoba. ${ }^{13}$

Este fragmento, escrito por el P. Martín de Roa (1615) sintetiza bien la idea de sacralización de los espacios urbanos y revela cómo operaba la devoción po-

${ }^{12}$ Libro de Privilegios de la ciudad de Sevilla, Estudio introductorio y transcripción Marcos Gómez Fernández, Pilar Ostos Salcedo y María Luisa Pardo Rodríguez, Ayuntamiento de Sevilla, 1993; GonZÁleZ JimÉneZ, Manuel (Ed), Diplomatario andaluz de Alfonso X, El Monte Caja de Huelva y Sevilla, Sevilla; Diego Ortiz de ZúÑIGA, Anales eclesiásticos y seculares de la ciudad de Sevilla, Guadalquivir, Sevilla, 1988.

${ }^{13}$ P. Martín de RoA, Flos sanctorum. Fiestas $i$ santos de la ciudad de Cordova. Algunos de Sevilla, Toledo, Granada, Xerez, Ecija, Guadix, i otras ciudades, i lugares de Andaluzía, Castilla, i Portugal. Con la vida de Doña Sancha Carillo, i la de Doña Ana Ponce de Leon condesa de Feria, Sevilla, 1615; Ambrosio Morales o. c.

Hispania Sacra, LXII

126, julio-diciembre 2010, 457-489, ISSN: 0018-215-X 
pular y el imaginario religioso, transformando los espacios en «lugares píos», en razón de la «presencia y permanencia de los santos»: «consagraron aquí con sus huellas las plazas i calles, por donde ahora andamos: las aguas, que bebemos, el río que gozamos, las casas donde vivimos»..$^{14}$

La presentación de los itinerarios de predicación fue también un aspecto fundamental que demuestra el interés por dar a conocer el mapa religioso de las ciudades y el modo en que éstas se ubicaban y articulaban en la geografía de la santidad hispana. Tal concepción permitió multiplicar las posibilidades de cada ciudad para ejercer sus derechos como «patrias temporales y espirituales».

Los autores realizaron una serie de consideraciones a la hora de establecer los vínculos de los santos con las ciudades. En el libro sobre los «Santos de Sevilla...» (1637), Antonio Quintanadueñas, jesuita, natural de Alcántara, las expuso así:

«Los dos títulos principales que hazen natural de una ciudad, y Diócesis a su santo, son el nacimiento temporal y espiritual. Patria madre suya los que nacieron en lugares de sus diócesis aunque murieran en otros. El nacimiento espiritual es su muerte o natural de los confesores o violenta de los mártires. La dignidad u oficio en él. Otro título es la posesión de su cuerpo o de gran parte de él, connaturalizándose con este modo de habitación. Por esto encargan tanto los santos, y concilios se veneren como propios los santos cuyas reliquias poseemos». ${ }^{15}$

Este mismo pensamiento lo encontramos en Bartolomé Sánchez de Feria y Morales, médico y literato cordobés, autor de «Palestra Sagrada o memorial de los santos de Córdoba...» (1772):

«Los santos ilustran tanto los Pueblos, que su nacimiento, su crianza, su habitación, su muerte, sus reliquias honran con especialidad los Países que disfrutaron su asistencia». .6

El criterio de la Iglesia explica por qué diversas Diócesis de España se atribuyeron la celebración de los mismos santos: por ejemplo, San Servando y Gervasio pertenecían a la Diócesis de León porque allí nacieron, a la de Cádiz porque allí murieron y a la de Sevilla porque en ella se encontraban sus reliquias. San Fulgencio a la de Cartagena porque allí desempeñó su oficio o dignidad, a la de Sevilla por su muerte y a Ecija y Placencia porque poseían sus reliquias. San Hermenegildo tuvo a Córdoba por «casa y refugio», porque la ciudad lo auxilió contra la persecución arriana y la ira de su padre Leovigildo, en tanto que

\footnotetext{
14 P. Martín RoA, Flos sanctorum..., 157v.

15 Antonio Quintanadueñas o.c. 6.

16 Bartolomé SÁnchez de Feria y Morales, Palestra Sagrada o memorial de los santos de Córdoba con notas y reflexiones críticas sobre los sucesos de sus historias, Córdoba, 1772, T. I, 171.
} 
Toledo debía gloriarse por su nacimiento, Sevilla por haber sido su rey y la ciudad, su corte y primera cárcel, Valencia por su destierro, Tarragona por su muerte y Aragón por erigir allí su sepulcro. ${ }^{17}$

Desde este punto de vista, esa situación no era un problema, no implicaba un perjuicio para las ciudades, al contrario, tenía un efecto positivo si se tiene en cuenta la proyección de las devociones más allá del ámbito jurisdiccional urbano. Por tanto, significaba mayor gloria para la religión cristiana, para los santos y las ciudades.

En estos ejemplos vemos que la Iglesia definió y amplió la proyección espacial y cultural del culto a los santos, aunque se tratase del patrono de una ciudad en particular. Indudablemente influía en esta difusión la especialización de los poderes atribuidos al santo, sus milagros, y la relación con los devotos, por la identificación con ciertos aspectos de su experiencia religiosa y de vida. Es decir, existía un complejo sistema de funcionalidades sociales, que podían usar instituciones civiles y eclesiásticas, según una tipología que iba desde el patronato oficial de grupos corporativos, colectividades urbanas a entidades nacionales.

A pesar de compartir las ciudades devociones comunes, cada una se reconoció diferente a las otras, cohesionada por la veneración a sus santos. En su culto cristalizaba la pertenencia a una comunidad, porque bajo su advocación se aglutinaban las corporaciones y las solidaridades de los habitantes de las distintas collationes o parroquias de las ciudades.

¿Por qué pudo difundirse una misma devoción? Sabemos que la provincia Bética estaba situada en una zona de notable tráfico comercial, de importantes ciudades y bien comunicada por vías terrestres y fluviales. Esos factores pudieron influir en la propagación. Por otra parte, junto con las migraciones de población, provocadas por la invasión de bárbaros y luego de musulmanes, se produjo la difusión del culto y las devociones de santos andaluces a otras ciudades y tierras de España, en ese proceso tuvieron un papel clave los monjes, por ejemplo los de Córdoba que fundaron monasterios en el norte, trasladando reliquias, lo que llevó a incluir la veneración y las fiestas en los calendarios locales de otras comunidades.

Otros medios de difusión fueron los textos hagiográficos y las «pasiones» de los santos-mártires que circularon por las bibliotecas de las Iglesias de España. La tradición oral también contribuyó a la propagación de las vidas de los santos y sus milagros. Asimismo, los peregrinos y viajeros favorecieron el trasvase de devociones. Y por último, los obispos difundieron el culto y las devociones a través del intercambio de libros de sus bibliotecas y las reuniones conciliares.

17 Ibidem 172.

Hispania Sacra, LXII

126, julio-diciembre 2010, 457-489, ISSN: 0018-215-X 
Todas estas proyecciones culturales y cultuales hicieron de las ciudades focos de influencia religiosa.

Sin embargo, debieron existir ciertas controversias que se pueden detectar por las diversas formas en que las fuentes trataron de establecer los vínculos que unían a las ciudades con sus santos. La Iglesia se basó no sólo en el martirologio romano -porque no siempre se ocupó de señalar los lugares de pertenencia de los santos- sino en los testimonios que procedían de varones piadosos y en aquellos cuya autoridad y antigüedad los hacía fiables. Ante la duda para fijar la «patria principal», se optó por la ciudad que celebrara su fiesta y devoción con mayor solemnidad.

Así, cada Diócesis se interesó por divulgar y hacer cumplir prácticas religiosas relacionadas con la veneración, la devoción y celebración, dedicadas a los santos de sus ciudades. Lo mismo hizo el Papa. Gregorio XIII, a petición de las iglesias de España, aclaró la Bula de Pío V, que concedía oficios propios a los santos de las provincias, y estableció en 1573 una nueva Bula para que cada Diócesis pudiera celebrar los santos de la ciudad, por ser sus patronos o poseer sus reliquias, aunque no estuviesen en el Breviario. Con la aprobación pontificia, cada arzobispado y obispado promovió las devociones y fiestas de sus santos, contribuyendo decisivamente la Iglesia a reafirmarlos como símbolos de identidad de cada comunidad y a profundizar una corriente renovada de espiritualidad. De este modo, la fiesta se convirtió en motivo de «patriotismo ciudadano»: «Dios había señalado para las ciudades santos y mártires ilustres que debían ser venerados y honrados», así que estas celebraciones, establecidas por el calendario, eran la ocasión para que los fieles reivindicaran la ciudadanía de sus patronos y protectores.

Como vemos, la historiografía continuó reelaborando y actualizando una tradición nacida en los primeros tiempos del cristianismo: el culto a los santos de las ciudades, símbolos y referentes obligados a través de los cuales las comunidades manifestaban su unidad y voluntad de vida colectiva. Reafirmó así la idea de un patronazgo especial ejercido sobre el lugar en el que se encontraban sus reliquias, convirtiendo a los santos en custodios acreditados de sus muros y habitantes, en fundadores de las iglesias locales, en sus defensores, protectores e intercesores privilegiados. ${ }^{18}$ Tal vinculación de los santos con las ciudades se manifestó con particular vigor allí donde el particularismo local y el patriotismo ciudadano estaban muy desarrollados. Si en las coordenadas espaciales presentadas por la historiografía destaca el localismo, el culto a los

\footnotetext{
${ }^{18}$ Entre los estudios hagiográficos que han marcado las tendencias actuales de investigación sobre estos temas hay que mencionar el dedicado a la Antigüedad Tardía por Peter BROwN, The cult of saints. Its rise and function in Latin Christianity, Chicago, 1981 y a la Plena Edad Media por Paolo GolineLLI, Cittá e culto dei sati nel medioevo italiano, Bologna, 1991.
} 
santos locales, estuvo motivado por el deseo de marcar la especificidad del lugar, de prestigiarlo con la «presencia» de santos que honraban a las ciudades.

\section{POSESIÓN Y TRASLATIO DE RELIQUIAS-SANTAS}

El cristianismo y las sensibilidades religiosas han sido un campo sumamente rico para el análisis de los símbolos y significados de la santidad. ${ }^{19}$ Los santos y sus reliquias se convirtieron en signos visibles y efectivos que garantizaban la comunicación entre el mundo celestial y terrenal y lograban anular la separación física y temporal. Configuraron el universo de lo sagrado, localizado en unas coordenadas espaciales muy precisas que jerarquizaban a las ciudades. La Iglesia reafirmó esta vinculación entre la «patria celeste y la terrestre», poniendo de relieve la «presencia permanente» de los santos en las sociedades. ${ }^{20}$ Esa «perdurabilidad» quedaba probada en la relación ciudad-santidad que las historias urbanas y eclesiásticas presentaron a través de inventarios de reliquias que Iglesias y ciudades poseían y de los testimonios de milagros o «hechos maravillosos» in vita o post mortem. Los creyentes tenían de esta forma signos efectivos de una perfecta comunicación garantizada por la «presencia y mediación» de los santos. Presencia, mediación, tutela, protección, que, para la mentalidad cristiana, se realizaba frecuentemente a través de los restos corporales de los santos y mártires y de sus objetos de uso cotidiano, que conservaban el favor divino que habían gozado en vida. Así pues, para los fieles, las reliquias encerraban fuerza taumatúrgica. ${ }^{21}$

19 Para referirnos especialmente a los cuerpos-reliquias, hemos de tener en cuenta que se han realizado importantes estudios en torno a las diferentes concepciones sobre el cuerpo y sus representaciones, desde una doble perspectiva, material y espiritual. Jacques LE GofF y Nicolás Troung, Una historia del cuerpo en la Edad Media, Paidós, Buenos Aires, 2005; George Vigarello, Historia del cuerpo. Del Renacimiento a la Ilustración, Taurus, 2005; Jean-Claude SchMitT, Le Corps, les rites, les rêves, le temps. Essais d'anthropologie médiévale, París, Gallimard, 2001.

20 Ángeles García DE LA Borbolla, «La materialidad eterna de los santos sepulcros, reliquias y peregrinaciones en la hagiografía castellano-leonesa (siglo XIII)», Medievalismo, Año 11, N 11, Madrid, (2001); «La praesencia y la virtus», La imagen y la función del santo a partir de la hagiografía castellano-leonesa del siglo XIII, Abadía de Santo Domingo de Silos, Burgos, 2002; La religiosidad popular. T. II Vida y Muerte: La Imaginación religiosa, C. Álvarez SANTAlo, Ma . Jesús BeIXo y S. RoDRÍGUEZ BECERRA (coords.), Barcelona, Anthropos, (2003); André VAuCHEZ, «El santo», El hombre medieval, (2 ed) Jacques LE Goff (ed.) Madrid, Alianza Editorial, 1995; Ariel GuiAncE, «Hagiografía y culto a las reliquias en la Hispania romana y visigoda: testimonios y mensajes», Sociedad y memoria en la Edad Media. Estudios en homenaje a Nilda Guglielmi, Ariel Guiance y Pablo Ubierna (eds.), Buenos Aires, Consejo Nacional de Investigaciones Científicas y Técnicas, Instituto Multidisciplinario de Historia y Ciencias Humanas, 2005.

${ }^{21} \mathrm{La}$ voz reliquia significa restos, residuos, no es específicamente cristiana, la sociedad de la Antigüedad Clásica compartía también esta idea de la persistencia de cierta forma de vida después de la muerte en los despojos corporales. Aunque la principal reliquia fue el cuerpo santo y el lugar que lo al-

Hispania Sacra, LXII

126, julio-diciembre 2010, 457-489, ISSN: 0018-215-X 
Estas creencias sobre la santidad, como fuente de poderes extraordinarios ante diversas necesidades, originaron comportamientos, actitudes, devociones, peregrinaciones, rogativas y procesiones. Todas ellas reflejaban las esperanzas, inquietudes y deseos de las sociedades.

Hay que recordar la gran influencia del discurso de la Contrarreforma, señalando la importancia del culto de los cuerpos de santos y mártires, por ser «intercesores necesarios». La Iglesia ennobleció sus cuerpos sagrados y realzó su veneración, pues habían sufrido y compartido el dolor de Cristo, abandonando el mundo para entregarse a Dios.22

La cuestión de las reliquias de cuerpos santos fue una de las controversias más importantes entre católicos y protestantes. Contra éstos, el Concilio de Trento reafirmó la doctrina de los Padres de la Iglesia: los cuerpos santos, al haber sido miembros vivos de Cristo y templos del Espíritu Santo, debían ser venerados, porque recordaban a los fieles que quienes tenían fe siempre vencían el martirio. ${ }^{23}$

Los predicadores, confesores y directores espirituales interpretaron los sucesos extraordinarios de los cuerpos santos como expresiones del alma. Sus cuerpos eran un medio de acceso a lo divino y una manifestación de la gracia. De sus restos, receptáculos de lo sagrado, emanaba una fuerza benéfica para los cristianos: los vivos la recibían situándose bajo su protección, y los muertos, encomendándose para el «más allá», de manera que tanto en la vida como en la muerte, las reliquias acercaron la «patria terrestre» a la «patria celeste».

El cuerpo-reliquia del santo era la encarnación de su permanencia en la comunidad y por eso a él se encomendaba el individuo en el nacimiento, en la vida y en la muerte. ${ }^{24}$ Por consiguiente, estos «tesoros» inestimables para las Iglesias y ciudades, poseían para los creyentes poderes para acabar con las sequías, prevenir las inundaciones, aliviarlos en las epidemias y guerras. De las reliquias esperaban la regulación de las estaciones, el aplacamiento del clima desfavorable y las fuerzas de la naturaleza, la seguridad, la salud, el abastecimiento, la paz y el bienestar general de las sociedades.

bergaba: la tumba, el santuario o depósito en altares de las iglesias, hay que recordar que existen otros tipos de reliquias: las reliquias reales no corporales (vestidos, instrumentos del martirio) y representativas (objetos santificados por el contacto con las reliquias reales y tumbas).

${ }^{22}$ En las devociones el cuerpo no era un obstáculo para el ascenso del alma, los textos medievales y de la Edad Moderna ven a la persona como una unidad, como cuerpo y alma, el cuerpo era portador de santidad, por tanto se lo concibe como instrumento y puerta que conducía al cielo.

${ }^{23}$ Los estudios de Georges Vigarello refuerzan esta idea sobre la gran significación de las reliquias en los siglos XVI y XVII. Para este autor, la Contrarreforma supo utilizar los cuerpos santos para convocar y mantener a los fieles dentro de la verdadera fe. Por lo contrario, los protestantes y erasmistas consideraron la veneración de reliquias como manifestación externa de la piedad, como expresión de la religiosidad relacionada con la superstición y la idolatría.

24 Jacques Le Goff y Nicolas TruONG, o. c.,143. 
Por todas estas razones, las ciudades y sus Iglesias difundieron en sus historias locales y eclesiásticas verdaderos inventarios de las reliquias que poseían, pues las engrandecían y «ennoblecían». ${ }^{25}$ La comprobación de su autenticidad no siempre se plantea en las fuentes, pues se manifiestan con absoluta seguridad y fe en las historias acerca de las que poseían las Iglesias. Se puede advertir que importaba menos saber si era un objeto original que probar que desempeñaba un papel de primer orden en la historia del cristianismo y que de él procedía su valor como objetos de culto y veneración. Estas declaraciones, muy comunes entre las Iglesias, dan cuenta que se trataba de un intercambio muy generalizado en la época porque las instituciones religiosas se presentaban como verdaderas coleccionistas, ya que las reliquias les proporcionaban prestigio y fama.

${ }^{25}$ Entre las santas reliquias confiadas para resguardo a la Iglesia Catedral de Sevilla, se encuentran las de su prelado y patrono San Leandro; los cuerpos de San Servando, San Germán y San Florencio; las reliquias de San Clemente; un brazo de San Bartolomé -según se cree fue traído de Roma, donado por el rey Fernando que enriqueció a la ciudad con muchos objetos sagrados- y parte de su pellejo; una canilla de San Sebastián; un dedo de la mano de San Blas; reliquias del apóstol San Andrés, de la Magdalena, del habito y silicio de San Francisco, del hábito de San Bernardo; reliquias de San Cristóbal, de Santa Inés, de Santa María Egipcíaca, de Santa Anastasia; una quijada de una de las once mil vírgenes. Asimismo, otras Iglesias de Sevilla poseedoras de reliquias fueron la de San Martín, Santa Marina, San Nicolás y el convento de San Francisco que tenía la cabeza de Santa Ursula, dádiva según se ha escrito de don Enrique de Guzmán, II conde de Olivares. Alonso Morgado, Historia de Sevilla en la qual se contienen sus antigüedades, grandezas y cosas memorables, Sevilla, 1587, cap. IV, 102103. Baeza también fue una ciudad enriquecida con numerosas reliquias corporales y representativas: el madero de la cruz, el cuerpo de San Pedro mártir; la Santa Iglesia poseía una custodia de plata que guardaban tres huesos de San Andrés y una parte del aspa con que fue crucificado; una imagen de Nuestra Señora hallada en el santuario del alcázar; un cofrecito pequeño con gran cantidad de reliquias que no se especifican; un pedazo de Lignum Crucis; una espina de la corona de Cristo. Gonzalo ARGOTE DE Molina-Ambrosio Montesino, Comentario de la conquista de la ciudad de Baeza y nobleza de los conquistadores della Enrique Toral (ed.) Diputación Provincial de Jaén, Área de Cultura, 1995, Libro III, cap. 175 y P. Francisco ToRRES, o. c. 113. Hay que destacar que las instituciones religiosas y eclesiásticas resguardaban otros objetos de igual valor sagrado que conferían gran prestigio a los lugares: las reliquias representativas, que hacían posible la veneración de los fieles e incluso «un viaje imaginario» en espíritu si no podían ir a Jerusalén, a Roma o a Santiago de Compostela. Jaén, se jerarquizó así con la posesión de la imagen de la Verónica, una de las representaciones de Cristo más famosas y veneradas de Occidente. Por otra parte, esta ciudad presentó un buen inventario de los denominados «instrumentos de la Pasión» o Armas Christi (la cruz, la lanza, la corona de espinas, los clavos, el látigo) que la Iglesia de la Contrarreforma exacerbó acentuando la dimensión dolorosa del martirio para transmitir como mensaje el triunfo de Cristo sobre el sufrimiento, la aflicción y la humillación y demostrar su amor y generosidad a toda la humanidad. Francisco Rus PUERTA, Historia Eclesiástica del Reino y Obispado de Jaén. Primera parte que contiene sus principios y progresos en la Religión cristiana. La predicación de los santos apóstoles Jacobo, Pedro y Paulo. Los santos y mártires así de Arjona, como de Baeza y otros lugares. Los obispos de quien se halla memoria. La historia, tradición y antigüedad de la Santa Verónica. Sitios de lugares antiguos con otras antigüedades dignas de ser sabidas desde el siglo I de la iglesia hasta el duodécimo, Jaén, 1634.

Hispania Sacra, LXII

126, julio-diciembre 2010, 457-489, ISSN: 0018-215-X 
La mayoría de las reliquias corporales de santos y mártires que poseían las ciudades eran parcelarias. La división a la que aludimos era el resultado de una costumbre de la que existen referencias en los siglos III y IV cuando las comunidades cristianas aún eran marginales. España no fue una excepción en estas prácticas y aunque estaban prohibidas pervivieron en el siglo VII. Tras la invasión musulmana, los creyentes visigodos practicaron esta parcelación, trasladaron partes a distintos lugares a los que emigraban, por temor a la profanación y para evitar la persecución, llevándolas a sitios más seguros, al norte de España, principalmente Toledo y León, centros religiosos importantes, donde se enterraban los monarcas, y a Navarra, Cataluña y Aragón. ${ }^{26}$

Veamos algunos ejemplos de traslatio de reliquias de las ciudades andaluzas reseñados por la historiografía. Estas noticias referidas a Sevilla, las registra Luis Peraza (1535), señalando que prudentísimos sevillanos, después de la batalla del rey Don Rodrigo, llevaron a Toledo y, desde allí, a Oviedo un arca de reliquias corporales y representativas que contenía una ampolla de cristal con sangre de Nuestro Señor Jesucristo, un madero de la Santa Cruz, parte de la piedra de su sepulcro, una parte de la corona de espinas, del manto y saja de Nuestra Señora, de los paños en el que Jesús estuvo envuelto en el pesebre, del pan con que alimentó a 900 hombres, del pan con que cenó con sus discípulos, del maná con que llovió a los hijos de Israel, de la tierra del Monte de los Olivos donde Nuestro Señor tuvo los pies cuando subió a los cielos, de la tierra donde puso los pies cuando resucitó a Lázaro; las manos del mártir San Esteban, la sandalia diestra de San Pedro apóstol, los cabellos con que Magdalena limpió los pies de Nuestro Señor, los huesos de profetas y santos. ${ }^{27}$

La traslatio aparece asimismo detallada en la obra de Alonso Morgado (1587), escritor extremeño y sacerdote en Sevilla. Explica el proceso de circulación de reliquias y su posterior descubrimiento o hallazgo por la intervención divina, que reveló a las ciudades dónde estaban: «los godos sevillanos pusieron cuidado en llevar reliquias para esconderlas en sierras y cuevas donde permanecieron hasta que el Señor las reveló a los cristianos». ${ }^{28}$ Las santas reliquias fueron llevadas a donde se había consolidado el dominio cristiano:

«Porque como quiera que las Reliquias de Sevilla eran muchas, muchos serán los Religiosos y devotos, que las alçarían, para escaparlas de las sacrílegas manos de los infie-

26 En relación a este tema Pedro Castillo Maldonado opina que las primeras traslaciones de reliquias corporales no siempre fueron para preservarlas de las invasiones, sino que fueron procedimientos utilizados para competir con el paganismo, es decir como portadoras de lo sagrado crearon otros espacios cristianos sacralizándolos.

${ }^{27}$ Luis Peraza, Antiquísimo origen de la ciudad de Sevilla y su fundación por Hércules Tebano y posesión de reyes que la habitaron en todos los tiempos hasta ser poseída de los moros, Sevilla, 1535, Libro VI, cap. III, 199-201.

${ }^{28}$ Alonso Morgado, o. c. Libro I, cap. XII, 23v. 
les. Y los unos tomarían un camino, y los otros tomarían otro, para donde llevarlas a esconder, conforme al desinio, que es de creer piadosamente, que nuestro Señor les inspiraría»

«Por donde es de creer, que asi como los de Toledo quisieron guarecer sus sanctas reliquias, y riquezas, en las Montañas y Asturias, los de Sevilla (entrandose la tierra adentro) se tuvieron por mas seguros la derrota de los Montes Pyrineos, y en aquellas partes de Navarra, y Cataluña, llevando consigo solamente las cabeças de aquellas santas, y sancto Príncipe Patronos suyos, y otras reliquias de otro tanto, o menos peso, dexando los sanctos cuerpos en sepulcros los mas escondidos, que ellos pudiesen, por no ir tan embaraçados, yendo como yvan huyendo inciertos del lugar, adonde la fortuna les echaría. Y como mucho de los Pueblos de los Reynos de Aragón no fueron entrados de los moros, mas antes después de averse defendido, se dieron a partido, y señaladamente Barcelona, y Zaragoza, y pudieron los cristianos de Sevilla, conservar, y esconder bien las sanctas reliquias de los sanctos, como escondieron, y guardaron los Tesoros, y otras cosas de mucha menor consideración». ${ }^{29}$

Si pasamos ahora a Córdoba, las fuentes narran que, en 1083, se trasladó de allí el cuerpo de San Zoilo -mártir, Dr. y arzobispo electo de Toledo- a Carrión, pero la más célebre de todas las traslaciones fue la del glorioso santo-mártir Eulogio: primero en la misma Iglesia «desde un sepulcro humilde a otro rico y bien labrado», el 1 de Junio (día de su fiesta) del año 868. Estuvieron en Córdoba sus reliquias hasta el año 884 que se las llevaron a Oviedo: un caballero que en Toledo había conocido las virtudes del santo, trató las paces del rey cristiano con el rey moro Mohamed para obtener una licencia y llevar el cuerpo de San Eulogio y Santa Leocricia, considerando que estarían con mayor reverencia en ciudades católicas. Concluida la paz, se llevó en secreto las reliquias y, conoci-

${ }^{29}$ Idem., 114. Con respecto a Sevilla, se escribe que el cuerpo de San Isidoro estuvo primero en la Iglesia de Santa Justa y Rufina, tras la invasión musulmana los cristianos lo escondieron en Itálica y en 1063 lo trasladaron a León -por orden de Fernando I- donde reposa en el monasterio que lleva su nombre. A las santas y mártires del S. III, patronas de Sevilla, Justa y Rufina, las noticias les dan destinos diferentes a sus restos-reliquias: unas cuentan que por medio de una revelación que tuvo el noble Pero Fernández de Castro, fueron trasladados los de ambas al monasterio de las Huelgas en Burgos; otra versión narra que se depositaron sus reliquias en una Iglesia de Asturias porque era un lugar que reunía las mejores condiciones para que los cristianos las escondieran; mientras otras dicen que se trasladaron al monasterio de Cartujos llamado Aniago, cerca de Simancas. Ambrosio Morales, o. c. Libro X, cap. XVI, 367. Poseyó también Sevilla el cuerpo y cabeza del rey Hermenegildo hasta que se apoderaron los moros de la ciudad. Los cristianos llevaron la cabeza con otras reliquias a Zaragoza, -dejando en Sevilla el cuerpo- de allí fue trasladada al Real Monasterio de Nuestra Señora de Sigena de religiosas del Habito de San Juan de Jerusalén en el reino de Aragón, hasta que Felipe II la colocó en San Lorenzo del Escorial. No obstante, otras reliquias de la cabeza se encuentran en el Colegio de la Compañía de Jesús y en la Catedral de Sevilla. Alonso Morgado, o. c., cap. IX, 113v-114. Asimismo, se cuenta que canónigos de Sevilla sacaron de la ciudad el cuerpo de San Fulgencio (hermano mayor de San Isidoro y San Leandro) obispo de Écija y después de Cartagena junto a otras reliquias y la imagen de Nuestra Señora de Guadalupe, para esconderlos en las breñas de Guadalupe, «por ser las más deshabitadas y desiertas de la tierra», donde permanecieron hasta que milagrosamente fueron halladas en tiempo de Alfonso XI. Alonso Morgado, o. c., cap. IX, 113-113v.

Hispania Sacra, LXII

126, julio-diciembre 2010, 457-489, ISSN: 0018-215-X 
da la noticia del tesoro que traía, el rey Alfonso salió con notable gozo y alegría con su corte -que se encontraba en Salamanca- y con su clerecía en procesión. Llevaron los santos cuerpos a la Iglesia Mayor de Oviedo, encerrándolos en un arca de ciprés, en la capilla de la santa, debajo del altar mayor. ${ }^{30}$ A raíz de este acontecimiento que dio lugar a la sacralización de distintos espacios y calles de la ciudad por donde pasaban, el historiador Andrés Morales y Padilla (1620) expresó: «Honró Dios esta insigne colocación con un milagro, sanando el rey a un paralítico por la intercesión de los gloriosos santos mártires». Finalmente en 1300 se hizo otra solemne traslación de estas reliquias a la Cámara Santa, a un arca de planchas de plata, por orden del Obispo Fernando Álvarez y a petición de Don Rodrigo Gutiérrez, Arcediano de Oviedo. ${ }^{31}$

Hay muchas noticias sobre los patronos de Córdoba. Ambrosio de Morales (1574) humanista, historiador, arqueólogo que fue cronista de Castilla en 1563, testifica que había reliquias de San Acisclo y Victoria desde el sigloVII en Medina Sidonia, en la ermita de Santiago del Camino. Según El P. Martín de Roa (1615), había reliquias suyas desde el año 668 en la Iglesia de San Saturnino en Tolosa (Francia), donde estaban las cabezas y gran parte de los cuerpos de los santos hermanos. Se cuenta también que en el monasterio benedictino de San Salvador de Breda, en Cataluña, había 62 pedazos de huesos de ambos santos, llevados de Córdoba en 1010.32 Los que quedaron en la ciudad natal, fueron trasladados a la Iglesia parroquial de San Pedro en 1125, del que se dice es «el lugar de mayor veneración en España». Por su parte, Bartolomé Sánchez Feria y Morales (1772) escribió que las reliquias de San Acisclo fueron enviadas por San Eulogio a Pamplona, al monasterio benedictino de San Román, cerca de la ciudad de Toro. ${ }^{33}$

Otros ejemplos que merecen destacarse son aquellos que dejan ver la intervención de la Divina Providencia en la elección de las ciudades receptoras de las reliquias santas, como sucedió con la traslación de las reliquias de San Fray Pedro Nicolás Pascual, de Valencia, obispo de Jaén y Baeza, mártir de los Padres Redentores de Nuestra Señora de la Merced. Este obispo, muy estimado por poblar de varones religiosos los conventos, fue apresado por los moros y llevado a Granada donde sufrió martirio en 1300. Los musulmanes permitieron el traslado de su cuerpo por «temor a que fueran castigados» y enviaron a Jaén y a Baeza mensajeros para anoticiar a las dos ciudades. Hubo entre ellas gran discordia por la posesión de sus reliquias. Para dirimir la cuestión se tomó una mula y se decidió que donde lo llevase allí se quedaría el santo cuerpo. La na-

\footnotetext{
30 Bartolomé SÁnchez de Feria y Morales, $o$. $c$., 354-355.

31 Andrés Morales y Padilla, $o$. $c$., Libro IV, cap. XIII, 443.

32 P. Martín de RoA, o. $c$.

33 Bartolomé SÁnchez de Feria y Morales, o. c., 354-355.
} 
rración cuenta que se produjeron muchos milagros pero el destino fue la Iglesia Mayor de Baeza, pues la mula entró por la puerta de la Luna. En recuerdo de este episodio tiene esta puerta una imagen del santo y otra la Iglesia del castillo de Jaén, en el convento de los Padres Descalzos. ${ }^{34}$

Recapitulando, la dispersión de las reliquias se percibió como algo positivo, pues permitía diversificar sus beneficios y extenderlos a otros fieles alejados de la ciudad, centro de su nacimiento o muerte, ya que se creía que cada parte conservaba el mismo poder que el todo. Más allá de los derechos e intereses que manifestaron las ciudades y sus instituciones religiosas y eclesiásticas, la dispersión multiplicó geográficamente y espiritualmente una misma veneración y devoción, integrando a las sociedades que estaban bajo su advocación. En este sentido, cabe aclarar que no hubo innovación, dichas prácticas religiosas existentes desde el inicio del cristianismo, se mantuvieron vigentes a lo largo de la Edad Media y la Edad Moderna.

Las traslaciones difundieron el culto a los santos. Sus cuerpos y reliquias crearon nuevos lazos religiosos de unión entre comunidades más allá del ámbito local y regional andaluz. ¿Con qué criterios se eligieron las ciudades? Por razones geográficas, defensivas, históricas y religiosas o de prestigio. Fueron decisivos los movimientos de población y también los monasterios, ambos hicieron posible la creación de vínculos entre espacios lejanos, incluyendo en el calendario local las fiestas en honor al santo trasladado. Otros dos factores fueron los concilios nacionales y la correspondencia entre los obispos y establecimientos eclesiásticos.

Las ciudades y sus sociedades exaltaron la pertenencia de los santos, pero valoraron también su traslación porque con ella se hacía efectiva la transferencia de su carácter sagrado hacia otros lugares: el santo podía estar en varios lugares a la vez, y, a través de sus reliquias, dispensar sus gracias a todos los que lo necesitaban y pedían.

En las fuentes encontramos expresiones que acentúan las consecuencias positivas de la dispersión, porque contienen alabanzas a España definiéndola como «semillero de santidad». Puede interpretarse que este fenómeno fue muy fecundo permitiendo el florecimiento de la fe y la devoción. En suma, la propagación de las devociones a través de la dispersión de las reliquias y la fundación de Iglesias, altares y capillas por distintas ciudades de España en honor de sus santos y mártires, ayudaron a configurar áreas de influencia espiritual de las ciudades convertidas en núcleos centrales de la geografía de la santidad.

34 P. Francisco de BiLches, Santos y santuarios del obispado de Jaén y Baeza, Madrid, 1653, cap. L, 143-147.

Hispania Sacra, LXII

126, julio-diciembre 2010, 457-489, ISSN: 0018-215-X 
La Edad Media conocía tres grandes centros de peregrinación conformado por tres ciudades sacralizadas por la posesión de reliquias: Jerusalén, Roma y Santiago de Compostela. Las ciudades andaluzas también quisieron formar parte de la geografía de la santidad en España. Ahora bien, la importancia dada a la sacralización no fue sólo reflejo de los intereses eclesiásticos ligados a la capitalización del peregrinaje asociado a la concesión de indulgencias para quienes acudieran al lugar. No lo fue por la centralización de donaciones y limosnas en donde se encontraba su sepultura, ni por buscar jerarquizar a sus Iglesias y órdenes religiosas, sino que tradujo la voluntad profunda de toda una comunidad de no separarse de las reliquias que la «regeneraban, salvaban y protegían» con sus poderes taumatúrgicos.

En la Edad Moderna, todos los lugares de culto procuraron adquirirlas mediante compra, intercambio o donación. Sobre todo desde fines del siglo XV, finalizada la Reconquista con la toma de Granada, los concejos urbanos y los cabildos catedralicios manifestaron gran interés por conservar, defender, dividir, agrupar, comprar o recuperar los tesoros santos que habían sido trasladados para restituirlos a las ciudades andaluzas.

El valor de su posesión desató una verdadera fiebre de reliquias que dio lugar a numerosos acuerdos entre distintas ciudades ${ }^{35}$ Hasta la monarquía se interesó por ellas. Felipe II reunió una riquísima colección de reliquias santas procedente de diversos lugares en el palacio de San Lorenzo de El Escorial. Encargó en 1572 al historiador Ambrosio de Morales que recorriera los reinos de León, Galicia y Asturias para recabar información sobre las reliquias de los santos, sepulcros reales, libros antiguos de monasterios e Iglesias para trasladarlos a su lipsanoteca, panteón y bibliotecas reales. ${ }^{36}$

Asimismo, existen constancias sobre las tratativas entre comunidades urbanas andaluzas, para recuperar las reliquias santas después de su antigua traslación o bien para establecer los derechos de los lugares donde debían depositarse. Las historias urbanas y eclesiásticas de los siglos XV, XVI y XVII demuestran la importancia de estos intercambios en las ciudades hispánicas. Revelan que las reliquias experimentaron una gran circulación, y muestran la política de las ciudades e Iglesias para lograr su restitución, para volver a ser lu-

35 Si bien las devociones y las sensibilidades religiosas se despertaron con las reliquias, el fenómeno provocó reacciones. La fiebre coleccionista no siempre agradó a los clérigos, ejemplo de ello fue el historiador jesuita P. Mariana, quien se preocupó por la falsedad y la simonía en el tráfico de objetos y cuerpos santos.

36 José Luis Bouza Álvarez, Religiosidad contrarreformista y cultura simbólica del Barroco, CSIC, Madrid, 1990; Ambrosio Morales, Viaje por orden del Rey D. Felipe II a los Reinos de León, Galicia y Principado de Asturias para reconocer las Reliquias de santos, sepulcros reales, libros manuscritos de las catedrales y monasterios, Junta de Castilla y León, Consejería de Cultura y Turismo, 2004. 
gares centrales de culto de sus santos, tras largos años en los que los territorios habían estado ocupados por los infieles..$^{37}$

Después de la Reconquista, el celo y religiosidad de los obispos los llevaron a recorrer los Pirineos, Asturias, Galicia y Cantabria para buscar reliquias e imágenes sagradas guardadas en las Iglesias. Intentaron devolverlas a los mismos lugares donde habían estado antes de la «pérdida de España». 38

El P. Martín de Roa (1615) comenta cómo Córdoba recuperó las reliquias de San Zoilo, que estaban en la villa de Carrión donde fueron llevadas en 1083 por el conde Fernán Gómez. En 1600 trató la ciudad y Juan de los Arcos, Fray de la Orden de San Benito, que el Abad de San Zoilo de Carrión, Fray Plácido de Huesca, les hiciese merced y honra a los ciudadanos de Córdoba de entregarle parte de sus reliquias «porque aunque no les faltasen por estar un poco mezcladas con las demás, que están en su iglesia de San Pedro, no las podían reverenciar tan en particular». ${ }^{39}$ La devolución o el regreso de las santas reliquias a su «lugar original», conseguido por medio de una prerrogativa episcopal y con apoyo municipal, dio lugar a que las ciudades receptoras o beneficiadas con su traslación, dispusieran celebraciones organizadas con gran solemnidad. La fiesta de la traslación fue un acontecimiento histórico para sus habitantes, tuvo mucho de representación teatral, poniéndose así de manifiesto el valor de los santos para la vida local.

Fray Juan Salvador Baptista Arellano, de la Orden Tercera de San Francisco (1626), mencionó la estima y amor de los habitantes de Carmona por su santo patrón, Teodomiro. En el año 1609, don Lázaro de Briones y Quintanilla, alférez mayor y regidor de la ciudad, con carta acordada y en nombre del estado eclesiástico y seglar, pidió al Obispo y a la ciudad de Córdoba una reliquia de su santo, que estaba en la Iglesia de San Pedro. El 2 de mayo, Carmona recuperó una canilla colocada en un cofre de plata. Fray Rodrigo Quintanilla de la Orden de Santo Domingo la recibió en compañía de muchos otros de la misma Orden y la depositaron primero en la Iglesia del monasterio de monjas Madre

\footnotetext{
${ }^{37}$ Desde el siglo XVI todos los países católicos se beneficiaron de la circulación y acumulación de reliquias santas. Italia fue sin duda el principal destinatario de ese tráfico piadoso, Francia no parece haberle ido a la zaga; había sufrido tanto por las profanaciones de los herejes que tenía que proceder a recargar de santidad muchos lugares de culto. Por su parte, también los cantones católicos de Suiza y los santuarios de la Alemania renana y meridional fueron clientes importantes. En esos países de sensibilidad barroca donde las sanas prácticas a menudo convivían con conductas mágicas, los relicarios se convirtieron a partir de finales del siglo XVII y sobre todo durante el XVIII en verdaderos objetos de arte que debido a la riqueza de las comunidades religiosas y a las ofrendas de los fieles no dejaron de aumentar.

${ }^{38}$ Alonso Morgado, o. c., Libro IV, cap. IX, 112

39 P. Martín de RoA, o. c., 114v.
}

Hispania Sacra, LXII

126, julio-diciembre 2010, 457-489, ISSN: 0018-215-X 
de Dios, hasta que la ciudad ultimara su lucida y solemne traslación en la que participaron Iglesias de Carmona y pueblos comarcanos:

«Despertó la alegría popular con prevenciones de su gusto, sacando toros a la plaza por 10 o 12 días continuos... dixeronse las vísperas, con música de vozes, e instrumentos, por los cantores de la Catedral de Sevilla, en compañía del clero, i Regiones, $i$ asistencia de la villa. Ordenose luego la procesión, i traxose en ella la santa reliquia en una grande, i rica custodia de plata, propia de la iglesia mayor de Carmona. El asseo de calles, ornato de paredes, arcos triunfales, fuentes, altares, castillos, e ingenios de fuego con otras muchas invenciones de gusto, i admiración, tan agradables fueron, como ejemplar la comun devocion, i alegría, con que todos igualmente, forasteros, $i$ naturales, procuraron aventajarse en servir, i onrar el recibimiento de la sagrada Reliquia del santo mártir su ciudadano. Quedose por aquella noche, alegre y festejada de todos con faroles, músicas, fuegos, $i$ otros públicos regocijos, en el altar mayor de la iglesia: i dicha al día siguiente la Missa solene, $i$ hecha otra procesión al derredor de la iglesia, por fuera de ella, la colocaron en altar propio dentro de la capilla del sagrario, donde pusieron también la imagen del santo, a quien todo el lugar acude con justa reverencia, i piadosa devoción, valiéndose en las ocasiones desta vida, de su socorro e intercession.»40

También las historias de Jaén contienen noticias sobre las reliquias de San Eufrasio, obispo de esta ciudad, y de Andújar. Bartolomé Jiménez Patón escribe (1628) que el rey Sisebuto fue muy devoto de este santo y en Andújar, lugar donde padeció martirio, le dedicó un suntuoso templo que duró hasta la «ruina de la cristiandad española». Cuando los cristianos volvieron no había memoria ni del sepulcro ni del templo hasta que en 1573 fue descubierto un brazo que se colocó en un templo dedicado al santo. Otra noticia da a conocer que su sepulcro se abrió en 1597 a instancias de la intervención y solicitud del poder real, para sacar una canilla que fue trasladada desde Galicia, donde estuvo sepultado en Valdenao, Priorato benedictino de San Julián de Samos. Con gran pompa y solemnidad la ciudad la recibió y colocó en un templo edificado unos años antes, que pertenecía a los religiosos de la Santísima Trinidad. La llegada de las reliquias del patrón de Andújar, «padre de la fe, primer maestro de la doctrina cristiana y primer obispo de su Iglesia», se organizó con gran júbilo y fiesta, sacralizándose el espacio urbano al pasearse las santas reliquias en procesión por sus calles. Acerca de ese acontecimiento comenta: «Todo lo mejor de Andalucía se juntó... hubo 8 días continuos de fiesta, artificios de fuego, luminarias, toros y corridas». ${ }^{41}$

\footnotetext{
40 Ibidem.,125 y 126; Fray Juan Salvador BaPtista ARellano, Antigüedades y excelencias de la villa de Carmona y compendio de historias, Sevilla, 1628, cap. XV, 92-93v.

${ }^{41}$ Bartolomé Jiménez PATON, Historia de la antigua y continuada nobleza de la ciudad de Jaén y de algunos varones famosos, Jaén, 1628, cap. VII, 20v-21 y 21v; Martín JIMENA JuRADO, Catálogo de los obispos de las Iglesias Catedrales de Jaén y Anales Eclesiásticos deste obispado, Estudio prelimar e índice J. Rodríguez Molina, y Ma . J. OsOrio Pérez, Granada, 1991, cap. III, 22-23.
} 
La recopilación de noticias sobre hallazgos y descubrimientos de reliquias e imágenes santas ocurridos a lo largo de la Edad Media y la Edad Moderna, formó parte del contenido de las obras historiográficas referidas a Andalucía. Sus autores dieron cuenta del «verdadero proceso de sacralización» que conllevaba al engrandecimiento y «ennoblecimiento» de sus ciudades y tierras. La proliferación de santuarios derivada de la inventio, marcó el desarrollo de cultos y devociones, desde una tendencia universalista, representada por las imágenes marianas, hasta una localista representada por las reliquias de santos de las ciudades y sus comarcas..$^{42}$

En estos extensos compendios, el Obispado de Jaén-Baeza puede situarse en primer orden porque las historias cuentan con varias referencias en las que se destaca que las ciudades veneraban con piedad cristiana, particular afecto y culto, reliquias santas e imágenes sagradas. El P. Francisco de Bilches, de la Compañía de Jesús (1653), narra que en 1595, Sebastián López, natural de la villa de Torres, encontró en una caverna inscripciones que le impulsaron a buscar reliquias de San Tesifón, iniciativa que fue aprobada por el Arzobispo de Granada, Pedro de Castro. El hallazgo dejó al descubierto «una mina de reliquias» entre las que se encontraban las de sus compañeros San Máximo y San Lupario, mártires de la época romana, en los principios de la Iglesia de Baeza. A partir de entonces, el lugar, la caverna del Monte Valparaíso, donde se cree que padecieron martirio estos santos, se transformó en el «sitio más honrado y venerado». Asimismo, la difusión de sus milagros influyó para que se erigiera de manera adecuada un lugar para custodiar los «tesoros santos» que la «Providencia Divina había guardado tantos años». Así se edificó un templo decente y conveniente, como lo requería todo espacio que la Iglesia y las devociones populares concebían como sagrado..$^{43}$

De aquellos «tesoros», aseguraba este autor, estaba lleno el Obispado. Eso probaba que sus ciudades fueron privilegiadas «porque Dios las había favorecido y enriquecido con tantas reliquias santas»: la Santa Verónica, la Virgen de la Capilla, la Virgen del Alba, la Virgen del Soterraño en Jaén; Nuestra Señora del

42 J. VILlafañé, Compendio histórico en que se da noticia de los milagros y devotas imágenes de la Reina de los Cielos y la Tierra María Santísima, que se celebran en los más célebres santuarios de España, Madrid, 1740; Honorio M. VElasco MAíllo, «Imágenes y santuarios: una aproximación desde los relieves y sombras de los relatos histórico-legendarios», en Salvador RoDRíGUEZ BECERRA, (coord.) Religión y Cultura, vol II, (1999); Carlos ÁlvAREZ SANTALÓ, «La escenografía del milagro hagiográfico y la construcción del milagro colectivo», en RODRÍGUEZ BECERRA (coord.), Religión y Cultura, vol. II, (1999); Salvador RodRíGUEZ BECERRA, «Santuarios y milagros en la religiosidad de Andalucía», Demófilo 16, (1999).

43 P. Francisco de BILCHES, o. $c$.

Hispania Sacra, LXII

126, julio-diciembre 2010, 457-489, ISSN: 0018-215-X 
Alcázar, Nuestra Señora de los Mártires y Nuestra Señora de la Peña en Baeza; La Virgen Nuestra Señora de la Cabeza, cuya devoción traspasó el marco local, difundiéndose por Jaén, Córdoba, Granada, Almería, Ciudad Real, Toledo, Avila, Salamanca, Guadalajara, Zaragoza, Lérida, Badajoz y Valencia, y la Virgen de Gocueca en Sierra Morena, Andújar. ${ }^{44}$

Gil González Dávila (1645) refirió el hallazgo de la Virgen de la Coronada de Jaén, imagen del tiempo de los visigodos, muy venerada por los reyes, «salvada por los cristianos ante la invasión musulmana». Unos labradores, de los primeros pobladores de la ciudad, plantando un árbol encontraron una campana y en un hueco de ella, la imagen que habían dejado oculta por 535 años. Por intervención de esta imagen -afirma- «obró Dios muchos milagros», por eso en el lugar del hallazgo se edificó una ermita. ${ }^{45}$

De gran devoción gozó también la Virgen de la Cabeza de Andújar. Su culto tuvo origen en el siglo XIII, cuando un pastor de Colmera (Granada) en 1227 encontró su imagen en la Sierra Morena, después de haber sido reconquistada la ciudad por Fernando III. Su santuario cuenta con una larga tradición de milagros y por ello es uno de los más importantes de Andalucía y España. ${ }^{46}$

Según Martín Ximena Jurado, historiador de Villanueva de la Reina, Baeza fue también escenario de «hechos maravillosos». En 1592 se produjo el hallazgo de una imagen de la Virgen de la Peña, talla que apareció en el camino de Jaén, en una cueva en la que había sido escondida por los cristianos cuando se produjo la invasión musulmana. Pero entre los «lugares religiosos», el P. Francisco de Bilches considera que el más famoso de esta ciudad fue el alcázar, donde entre 1628-1629, las monjas del convento de Santa Catalina vieron luces, escucharon música de campanas, instrumentos muy acordados y voces muy suaves en Pascua y en la fiesta de Nuestra Señora de los mártires de Baeza. Tales noticias dieron lugar en 1639 a procesiones y excavaciones, convirtiéndose aquel sitio en «monte sagrado» porque entre los hallazgos estaban los restos de los santos mártires Justo, Abundio, Sisinio, Víctor, Alejandro, Mariano y la imagen de la Virgen de los mártires con el niño Jesús en brazos. Con motivo de este y otros casos, las historias muestran que Baeza «se sembró de santuarios»

${ }^{44}$ Idem, 251.

45 Gil GonZález Dávila, o. c., T. I, 218.

${ }^{46}$ Enrique Gómez MARín, «La devoción popular de Nuestra Señora de la Cabeza de Sierra Morena en la Andalucía de los siglos XVI y XVII», en M. J. BuXo I ReY, S. Rodríguez Becerra, y L. C. Álvarez Santaló, (coords.), La religiosidad popular, T II, (1989); Juan Vicente Corocles DE LA VEGA, «Aproximación a la iconografía de la Virgen de la Cabeza de Andújar», en La religiosidad popular, T II, (1989); A. CEa Gutiérrez y J. C. Torres MartíneZ, «Retrato de un santuario: el pulso devocional de Nuestra Señora de la Cabeza en Andújar a través de un manuscrito inédito de Silos», en Salvador RodRÍGUEz BECERRA, Religión y Cultura, vol. II, (1999). 
con las reliquias encontradas en las Puertas del Conde, del Lobo, en torres y murallas. ${ }^{47}$

En Sevilla, Alonso Morgado (1587) cita la restitución de la imagen de Nuestra Señora «por orden del cielo al mismo y antiguo lugar donde estuvo en tiempo de los godos». Esta Virgen milagrosa, colocada en la Iglesia de San Julián, apareció debajo de una retama o escobera, en un monte que los catalanes llamaban «Ginesta», donde fue llevada cuando se produjo la invasión musulmana. ${ }^{48}$

Fray Juan Salvador Baptista Arellano (1626) afirma que la mayor nobleza de Carmona es tener por patrona y abogada a la Virgen María, Reina de Gracia. Cuando los moros tomaron la ciudad, los cristianos la escondieron entre los montes por no poder llevarla a otro sitio sin la conveniente reverencia y veneración. Cuenta la tradición que su imagen se apareció a un pastor en una cueva, y desde ese día toda la villa le rindió culto y devoción. Ese lugar, que «había sido albergue de fieras y animales», se transformó con la sagrada imagen, en «casa de paraíso» para sus fieles:49 "De forma que lo que antes era fragoso y nido, agora es montes, y peñascos del cielo, después que la Reyna de Gracia, madre de toda mansedumbre se dignó abaxar a ellos, desterrando de allí todo género de malezas, dexando llena la villa de bienes espirituales y divinos: y juntamente en sus vegas, y campiñas, abundancia de frutos temporales...».50

Con la «presencia» de imágenes santas, las sociedades experimentaron sentimientos de proximidad, cercanía y comunicación con el «paraíso celestial». Como en otros casos, en aquel lugar de veneración a la Virgen, Reina de Gracia, el cabildo secular de Carmona levantó en su honor una Iglesia en lo más llano de las breñas, a donde acudían muchos devotos para buscar su favor, por ello se dice:51 «... siempre que en Carmona ay aflicciones, trabajos y necesidades, el cabildo Eclesiástico y Secular, acuden con gran devoción a su sagrado Templo, con procesiones, rogativas, para que en nombre desta celestial Señora, alcancen el remedio della».

Hay también historias sobre los milagros en el sitio de la Fuensanta en Córdoba. Saliendo de esta ciudad, por la puerta de Baeza, con dirección a las «deleitosas riberas del celebrado Betis», se llega a un sitio llano y apacible, de gran devoción al que los cordobeses de la ciudad y su comarca asistían continuamente. El lugar, donde se alzaba un fuerte puente bajo el que se encontraba un arroyo que descendía de la Sierra Morena o «Montes Marianos», al que llaman

\footnotetext{
${ }^{47}$ Francisco de Bilches, o. c., 251. Rafael RodríGUez MoÑIno SoRIANo, o. c., 50-51.

48 Alonso Morgado, o. c., Libro IV, cap. IX, 116-116v.

${ }^{49}$ Fray Juan Salvador Baptista ARELlano, o. c., 282 y 283.

${ }^{50}$ Ibidem., 283v.

${ }^{51}$ Ibidem, cap. IX, 58v.
} 
Las Peñas, era «un sitio precioso donde la vista y el oído se recrean», con variedad de huertas, bellísimos narcisos, copiosos árboles y agua corriendo. Este «Paraíso terrenal» se convirtió en «lugar de singular consuelo, en santuario donde se favorecían el alma y el cuerpo».52 En efecto, la aparición de la Virgen Nuestra Señora, luego la invención o hallazgo de su imagen, y los milagros fueron las causas de que se operara esta transformación del lugar al que se denominó la Fuensanta, el sitio de mayor demostración de devoción, veneración y religiosidad de los cordobeses.

La aparición y revelación de la Virgen sucedió en el reinado de Juan II y en tiempos del obispo de Córdoba, Sancho de Rojas. La tradición dice que a Gonzalo García, vecino de la Parroquia de San Lorenzo de Córdoba, cardador de lana, hombre virtuoso y devotísimo de la Virgen, afligido por la enfermedad de su mujer e hija, se le aparecieron cerca del arroyo de las Peñas, dos mujeres hermosas y un mancebo: Nuestra Señora y los santos mártires patronos de la ciudad, Victoria y Acisclo, y le dijeron que, bebiendo del agua tendría salud él y su familia. Cumpliéndose estos hechos, desde ese momento muchos fueron los milagros que obró la Virgen allí a través del agua, de ahí el nombre de Fuensanta. ${ }^{53}$ Ciertamente con el tiempo, otro hecho reafirmó a este lugar como el «elegido por el cielo». Fue cuando un ermitaño halló una imagen de la Virgen con el niño Jesús en brazos, que se cree era del tiempo del rey Recaredo. Creció la fama de este lugar con los «sucesos maravillosos», transformándose en uno de los principales receptáculos de abundantes limosnas del cabildo de la Iglesia de Córdoba, que ordenó edificar allí un pozo, un gran humilladero y luego una Iglesia..$^{54}$ La devoción y el culto a la sagrada imagen creció con las noticias de sus milagros, lo que determinó que el cabildo viese la necesidad de un lugar más decente y de mayor honor para la Virgen, que fue trasladada a la nueva Iglesia concurriendo toda la ciudad en procesión general y con alegres demostraciones para su santa patrona, «amparo, consuelo, refugio, gloria y honra de este suelo». 55

Los milagros recogidos por las historias muestran cómo se había extendido la devoción de numerosos fieles que acudían y visitaban a la Fuensanta, encomendándose a ella, pero también cómo se promovía la veneración a Nuestra Señora. Los favorecidos fueron cordobeses, vecinos de la ciudad, cristianos, conversos, enfermos, personas en peligro, mujeres, hombres, niños y clérigos,

\footnotetext{
52 Enrique VACA DE AlFARO, Historia de la aparición, revelación, invención y Milagros de la soberana imagen de Nuestra Señora de la Fuensanta que se venera en su devotísimo santuario extramuros de la ciudad de Córdoba, desde el año de 1420, Córdoba, 1795 (reimpresión), cap. I, 3-5. y Bartolomé SÁNCHEZ de FERIA, o. c.,T. III, 11-23.

${ }^{53}$ Enrique VACA DE Alfaro, o. c. 8.

54 Ibidem., 25.

55 Bartolomé SÁnchez de Feria y Morales, o. c., T. III, 23.
} 
probando así que la consideraban «consuelo de la ciudad y su Diócesis». ${ }^{56}$ Esta devoción trascendió el reino de Córdoba, llegó a toda Andalucía, a España y a su imperio, porque desde las Indias se remitieron a la Fuensanta limosnas. ${ }^{57}$

Este espacio, sacralizado con la aparición de la Virgen, el hallazgo de su imagen y sus milagros, ha convertido a la tierra de Córdoba en un eje central del culto. La fama de este santuario y del cabildo de la Iglesia que tenía el patronato había sido tanta que de muy distintas tierras y regiones acudía gente a pedirle favores y en ella lo hallaban. Así se escribe que todos acudían a la Fuente «como a piscina» y los enfermos con admirables efectos con aquellas aguas quedaban curados. De este modo, la tierra de Córdoba recibió grandes alabanzas porque «tiene por dádiva del cielo una Fuente que con sus aguas la riegan, una fuente que la fertiliza, la Imagen de $M^{a}$. Santísima de la Fuensanta, de donde se derivan todas sus dichas, con su misericordia tiene asegurado su patrocinio». 58

No fue este el único caso de famosas imágenes marianas protectoras de Córdoba. La imagen de Santa María de la Salud, hallada dentro de un pozo, la descubrieron arando la tierra Simón de Toro y Bartolomé de la Peña, vecinos de Córdoba, del alcázar viejo frente a la puerta de Sevilla, extramuros de la ciudad. En su honor se hizo una pequeña Iglesia que fue lugar muy venerado, porque se cree que allí estuvo el monasterio de San Ginés donde fueron sepultados algunos mártires. Otra imagen de Nuestra Señora del Pozo se halló en una ermita de San Rafael, en la casa del presbítero Andrés de las Roelas. Y a dos leguas de Córdoba en un pilar o pozo de una hacienda del Real Convento de San Pablo, se halló también, milagrosamente, la imagen de Nuestra Señora del Pilar. ${ }^{59}$

\footnotetext{
${ }^{56}$ Entre los milagros se menciona la recuperación de un vecino de Córdoba enfermo; la curación de una mujer judeo-conversa; a Hernando de Molina de la ciudad de Córdoba que en 1548, apresado en Tolosa (Francia) por los enemigos, se encomendó a la Virgen y lo puso a salvo; a Juan del Monte a quien la Virgen cuidó mientras navegaba, a su regreso de Canarias, sosegando el mar durante la tormenta; al hijo de unos vecinos de Córdoba que en 1554 se cayó al pozo del humilladero y se salvó con ayuda de Nuestra Señora; a un vecino herido en la guerra de Granada, en las Alpujarras en 1571, que se encomendó a la Virgen; a una mujer que había perdido el habla y se curó en 1588, y a un jurado de la ciudad que estaba desahuciado y se recuperó. En definitiva ha resucitado muertos, dado vista a ciegos, sanado paralíticos, hidrópicos, cojos, mancos y de otras graves y peligrosas enfermedades los ha liberado... en necesidades de agua se halla con su intercesión abundantísima pluvia, por todo ello comenta Enrique de Vaca de Alfaro, «es muy numeroso en concurso de toda Andalucía y la mayor devoción de Córdoba. Príncipes, señores de toda la región envían a Nuestra Señora riquísimos presentes y alajas costosísimas», en Historia de la aparición, revelación, invención y Milagros..., cap.III, 89 y 90-91.

${ }^{57}$ Enrique VACA DE Alfaro, o. c., 89.

58 Bartolomé SÁnchez de Feria y Morales, $o . c .$, T. III, 11.

${ }^{59}$ Ibidem., 40-41; P. Martín de ROA, Veneración y fruto de las sagradas imágenes i Reliquias. Historias i exemplos a este propósito, Sevilla, 1626.
}

Hispania Sacra, LXII

126, julio-diciembre 2010, 457-489, ISSN: 0018-215-X 
Con tantos ejemplos milagrosos, Bartolomé Sánchez de Feria y Morales elogia de este modo a la tierra de Córdoba:

«Ciertamente admira ver que solo en Córdoba haya tantas célebres Imágenes aparecidas, y milagrosas, cuyo número excede sin duda a otras Poblaciones del mundo. Bendito sea el Señor, que tantas mercedes le hizo, y nos hace a los que nos creó en este (por tantos títulos suyo) Pais: y bendita sea la Madre de Misericordia, que quiso con tantas pruebas demarcar por suyo el Pais, donde antiquísimamente se le tributan tantos cultos». 60

Nos preguntamos ¿por qué se dio en Andalucía esta proliferación de invenciones de imágenes y reliquias? ¿A qué intenciones u objetivos respondía su difusión a través de la historiografía? La idea que domina en estas obras es que la Iglesia transmitió a los fieles la certeza de que los santos «elegían los lugares para permanecer eternamente» en ellos, habían escogido un pueblo, una comunidad. Eso ennoblecía y engrandecía a sus ciudades. El hallazgo de imágenes y reliquias santas tuvo en Andalucía características particulares. Vista en conjunto la región, las historias parecen plantearnos que los lugares santos o sacralizados estuvieron en todas partes, hasta incluso conformándose ciertas rivalidades y competencias entre las ciudades. Eso se desprende de la lectura de un extenso repertorio de lugares que, a través de la inventio, pasaban a formar parte de la geografía religiosa de Andalucía y España.

En ese sentido, las imágenes y las reliquias santas fueron elementos capitales para definir a las ciudades andaluzas como espacios simbólico-religiosos, para sacralizar sus territorios, jerarquizándolos, engrandeciéndolos y ennobleciéndolos. Todo ello tuvo un efecto multiplicador de lugares de peregrinación que atraían a las poblaciones urbanas y de la comarca y se convertían en centros articuladores de devociones y de distribución de gracias. ${ }^{61}$

Como hemos visto, especialmente en el reino de Jaén la producción historiográfica de contenido eclesiástico o hagiográfico recibió, según José Rodríguez Molina, un impulso mayor en el siglo XVII (entre 1630 y 1670). Esas obras debían su edición al auspicio y mecenazgo del cardenal Baltasar Moscoso y Sandoval, pero también se compusieron en un contexto de condiciones generales desfavorables, descenso demográfico, recesión económica, epidemias,

\footnotetext{
${ }^{60}$ Bartolomé SÁNCHEZ de Feria y MoRALES, o.c, 43.

${ }^{61}$ Roberto FERNÁNDEZ SuÁREZ, «Geografía religiosa y ermitas: la focalización de los símbolos sagrados», en Religión y Cultura II, ob. cit; Honorio M. VelasCo MAILlo, «La apropiación de símbolos sagrados. Historias y leyendas de imágenes y santuarios (s.XV-XVIII)», Revista de Antropología Social, vol 5, Ed. Complutense, Madrid, (1996); S. RodríGuez BeCERra y E. Gómez MarTínez, (coords.), «Santuarios andaluces», Demófilo 16 y 17, Fundación Machado, (1995); William Christian, Apariciones en Castilla y Cataluña (s. XIV-XVI), Madrid, 1990 y Religiosidad local en la España de Felipe II, Nerea, Madrid, 1991.
} 
malas cosechas, que impulsaron a una profunda religiosidad y devoción. La sociedad jiennense recurrió a la Iglesia, especialmente a los pósitos y graneros eclesiásticos, y a los santos pidiendo auxilio, asistencia y alivio de sus males. Hubo en todo el Obispado, milagros, visiones, apariciones, invenciones de imágenes y reliquias. Todo el Reino se convirtió en escenario elegido por la Virgen y los santos, como lugar privilegiado para quedarse.

Junto a este afán laudatorio y encomiástico de las ciudades, se promovió el trabajo arqueológico con excavaciones en Arjona, Villanueva, Andújar y Baeza, que tenían como fin descubrir sus «ricos tesoros» para rendirles culto y veneración. La pasión por la arqueología respondía muy bien a los intereses de la Iglesia, y contribuyó a acrecentar la sacralización urbana y rural, a elevar el prestigio de las ciudades y sus tierras. Asimismo, hubo especial interés por mostrar que los hallazgos de imágenes y reliquias fueron «hechos maravillosos», es decir excepcionales, extraordinarios, por tanto no se trataba de escribir que las Iglesias, monasterios y conventos los habían adquirido por compra, donación o por la obra de un artista que las tallaba o esculpía, sino al contrario, de presentarlas como signos de Dios a sus comunidades.

Esta literatura se encuadraba en las doctrinas del Concilio de Trento, donde se puso de manifiesto que la Iglesia defendía y promovía la veneración de las imágenes y las reliquias. Precisamente en esta sintonía, el P. Martín de Roa, jesuita, compuso una obra (1623) que contenía enseñanzas y los principales fundamentos de la Iglesia Católica, respondiendo a las críticas del protestantismo sobre el culto a las imágenes y a las reliquias. En ella explicaba que, desde los primeros tiempos, la Iglesia hizo uso de las imágenes. Su veneración no significaba idolatría, sino demostración de fe. Su uso estaba fundado en la necesidad de la naturaleza humana de apoyar sus creencias en los sentidos, porque ver y tocar eran casi imprescindibles. Reconocida así la importancia de los sentidos en la experiencia religiosa, se consideró que como la vista ejercía el señorío sobre el corazón, era una puerta para llegar al alma, así afirmaba: «...el mismo Dios nos enseña las cosas invisibles por las visibles, el espíritu por el cuerpo. El agua del sagrado baptismo enseñança es de la purificación, que por la Divina Gracia, obra este sacramento en el alma. Los accidentes del pan, i el vino, que los sentidos perciben en la Eucharistía, fielmente enseñan el sentido interior, que nos da el precioso Cuerpo, $i$ sangre de Jesucristo». ${ }^{62}$

En primer lugar, las imágenes corporales enseñaban las cosas espirituales. Percibidas y captadas por los sentidos, remitían a lo invisible, llegaban al espíritu, sobre todo grababan enseñanzas para la gente menuda, por eso los Padres de

62 P. Martín de RoA, Veneración y fruto de las sagradas Imágenes, Reliquias. Historia i exemplos a este propósito, Sevilla, 1623, cap. VII, 40-42.

Hispania Sacra, LXII

126, julio-diciembre 2010, 457-489, ISSN: 0018-215-X 
la Iglesia llamaban a las imágenes el «Libro de los ignorantes», porque, a través de ellas, aprendían lo que la gente docta comprendía y conocía con la lecturas de los textos. Así pues, la devoción y la fe recorrían un itinerario, desde los sentidos al espíritu. ${ }^{63}$ En segundo lugar, las imágenes despertaban y encendían el amor a Dios y a los santos. En tercer lugar, incitaban a la imitación de las virtudes de aquellos que representaban, porque se las consideraba espejos donde los cristianos debían buscarse y mirarse, y hallándose distintos y muy alejados de esos ejemplos, por ser hombres imperfectos, los alentaba a seguirlos. ${ }^{64}$ Por último, las imágenes constituían un pilar fundamental en la profesión de fe de los cristianos. De ellas recibían múltiples beneficios porque eran el consuelo, socorro y remedio en todo momento. ${ }^{65}$

Por todas estas razones, los hallazgos de imágenes y reliquias santas fueron legitimadas por la Iglesia. Ambas recordaban a los habitantes de las ciudades con cuántos abogados, intercesores y protectores contaban.

Si bien la región andaluza conoció una abundancia de hallazgos de imágenes santas, hay que aclarar que los mismos aires descubridores recorrieron otros lugares de la península, no obstante, la historiografía quiso mostrar un panorama diferencial del resto de España. Andalucía parecía situarse así en el primer rango, dando cuenta que Dios la había elegido y el cielo la había bendecido y enriquecido.

Interesa señalar la importancia de los lugares dedicados a la devoción mariana en Andalucía. Sabemos que los santuarios proliferaron durante la Reconquista cristiana y que, gracias a sus apariciones y milagros, a favor de los cristianos frente a los musulmanes, se acrecentaron las devociones y advocaciones. La hipótesis que en su momento formuló William Christian es que Andalucía se vio en muchos casos privada de sus auxiliadores divinos, durante la invasión musulmana, por el traslado de sus reliquias. La Iglesia cubrió ese vacío con otra presencia sagrada, la de la Virgen, intercesora universal, no especializada, madre de toda la comunidad. Sin embargo, las historias minimizan esa aludida «pobreza en la sacralización» de las ciudades. No se trataba de compensar una presencia santa por otra, ni de presentar ese fenómeno como algo exclusivo de la Reconquista cristiana en el siglo XIII, porque la dedicación de espacios rurales, prados, caminos, grutas, cuevas, ríos, y urbanos, calles, plazas, fuentes de agua, siguió acrecentándose aún cuando las comunidades andaluzas emprendieron en los siglos XV, XVI y XVII la recuperación y restitución de las reliquias de sus santos locales. ${ }^{66}$

${ }^{63}$ Idem, cap. VII, 40-42.

${ }^{64}$ Ibidem, cap. VII, 47v.

65 Ibidem, cap. IX, 59.

66 William CHRISTIAN, «De los santos a María, patrona de las devociones en santuarios españoles desde el principio de la Edad Media hasta nuestros días», Temas de Antropología española, Madrid, 1996. 
APARICIONES DESDE EL «MÁS ALLÁ»

En la historiografía medieval hispánica existen numerosas noticias sobre la función mediadora y protectora de la Virgen y los santos en tanto que auxiliadores de los cristianos en las guerras de frontera contra el Islam, e intercesores en la conquista de las ciudades andaluzas. Como se sabe las apariciones milagrosas fueron entendidas como signos de intervención divina en la tierra, un hecho maravilloso, extraordinario.

Los relatos sobre este fenómeno religioso reafirmaron la idea providencialista de la historia de España y le otorgaron una interesante funcionalidad tanto en la Edad Media como en la Edad Moderna. Fueron sobre todo un medio privilegiado y eficaz para revelar la proximidad y el contacto de lo sagrado con una sociedad, que se sentía eminentemente cristiana y quería dar cuenta de la presencia permanente de los santos en su espacio.

En la Edad Media, las apariciones de los santos se vincularon al rescate y redención milagrosa de cautivos cristianos. Estas leyendas y tradiciones respondían a las necesidades de las sociedades de frontera, como fue la andaluza en la Edad Media. En esos casos, las figuras celestiales simbolizaban las esperanzas y el consuelo de quienes estaban en peligro permanente. El segundo tipo de apariciones pertenece también al contexto de la Reconquista, pero cumplían una función político-religiosa capitalizada por la monarquía. Se trata de la intervención milagrosa en la restitución de las ciudades. En estos casos, los «elegidos» fueron los reyes, testigos de apariciones, revelaciones, o protagonistas de visiones en las que los santos y la Virgen anunciaron que tenían la misión de defender la fe y los reinos cristianos. ${ }^{67}$

En la Edad Moderna, las apariciones reflejaron la religiosidad popular, los ideales utópicos de la sociedad, las críticas al mundo y tuvieron una finalidad moralizante. Las historias urbanas y eclesiásticas contienen también ejemplos sobre las «apariciones» de los santos a clérigos y fieles laicos para indicarles dónde estaban los cuerpos- reliquias de sus santos, para que fuesen cumplidamente venerados. En estos discursos se advierte también intenciones propagandísticas, el afán de las ciudades andaluzas y del clero por demostrar la «volun-

\footnotetext{
${ }^{67}$ San Isidoro y San Andrés ayudaron a la conquista de Baeza; San Miguel a la de Úbeda; Santa Catalina a la de Jaén; San Acisclo a la de Córdoba; la Virgen de los Reyes o de la batalla a la de Sevilla. P. Francisco de BILCHES, o. c., cap. XXXVI, 93, 95 y 97; cap. XLV, 130-133. Gil GoNZÁLEZ DÁvILA, o. c., T I, 216; Ambrosio Morales, o. c., cap. XXIII, Libro X, 379v y 380. Véase otros casos de viajes de personajes celestiales, apariciones y visiones en Ariel GuIANCE, «Sobre el espacio y el tiempo de trasmundo en la literatura castellana medieval», Temas Medievales 2, Bs. As., (1992); «Las apariciones de los santos en la hagiografía altomedieval castellana: estructura y función», Temas Medievales 9, Bs. As., (1999) y «Santos y taumaturgia (siglos XII-XIII)», Temas Medievales 5, Bs. As., (1995).
}

Hispania Sacra, LXII

126, julio-diciembre 2010, 457-489, ISSN: 0018-215-X 
tad de Dios», a través de sus intermediarios los santos, portadores de anuncios y de revelaciones, para convertir a distintos lugares en «espacios privilegiados», transfiriendo a ellos un carácter sagrado.

En 1575 se difundió en Córdoba la noticia de la aparición de San Rafael al padre Andrés de las Roelas, vecino de la colación de San Lorenzo, para señalarle que en la iglesia de San Pedro reposaban, guardadas, las reliquias de los mártires Fausto, Januario, Marcial, Zoilo, Acisclo, Victoria, Perfecto, Sisenando, Pablo, Cristóbal, Leovigildo, Teodomiro, Flora, María y Sebigotho.

El obispo de Córdoba ordenó restaurar la capilla de San Pedro y hacer un arca de plata para guardar los huesos de 18 santos y mártires encontrados. En ese contexto, se produjeron algunos milagros anunciados por San Rafael a Andrés de las Roelas (1578), incluso este clérigo lo experimentó en su propia persona, gozando de salud de forma milagrosa. Este hecho legitimó el mensaje del santo a su portavoz, y al hallazgo en el sepulcro de la iglesia. La identidad de las reliquias encontradas fue aprobada por el Concilio Toledano de 1582 y en 1588 el Papa Gregorio XIII decretó que se veneraran. ${ }^{68}$

Un tipo de asociación particular de los santos con su comunidad la encontramos en la intervención de San Pablo en 1436 en Ecija. El relato de los milagros que obró el santo patrón de la ciudad refleja la preocupación de la Iglesia sobre los comportamientos y prácticas de sus fieles. Según los testimonios, el apóstol se apareció para transmitir el mensaje de Dios a sus habitantes que se habían apartado de los deberes cristianos con sus pecados. Juraban en falso, blasfemaban, no hacían obras de caridad ni daban limosnas a los pobres, no guardaban los días festivos instituidos por la Iglesia. Esta intervención buscaba corregir y disciplinar a los moradores de Ecija para que fuesen «bienaventurados» y cumplieran con las penitencias, la comunión y la confesión.

La Iglesia capitalizó este mensaje para encauzar e inculcar las prácticas de la población y contó con la colaboración del cabildo secular para celebrar una procesión. Ambos poderes trataron de convencer a los fieles de que el cumplimiento de los deberes religiosos redundaba en bien para ellos y la ciudad. El mensaje confirmaba la insistencia de la enseñanza de la Iglesia: «ningún ciudadano noble, plebeyo, rico o pobre esté exento de las obligaciones como cristianos». Hacía tiempo que señalaba la degradación de las costumbres y las críticas iban dirigidas especialmente a los grupos influyentes y privilegiados, según los comentarios del P. Martín de Roa: «Telas son de araña las leyes, no prenden sino viles mosquitos los mayores animalillos las rompen. Pecadores son de privilegio los poderosos, e ningunos mas que los oficiales públicos, pues no con-

68 Bartolomé SÁNCHEZ DE FERIA, o. c., T IV, 260.

Hispania Sacra, LXII 126, julio-diciembre 2010, 457-489, ISSN: 0018-215-X 
tentos con ser essentos en sus personas, essenciones, libertades, venden de culpas, con igual interés suyo, que daño a la República». ${ }^{69}$

En este caso, la Iglesia supo aprovechar los discursos hagiográficos para anunciar mensajes religiosos de los santos y las apariciones para catequizar a amplios sectores de la sociedad, para amonestar a los fieles por faltas cometidas sobre conductas específicas.

$$
* * *
$$

En síntesis, la relación de los santos y las ciudades puede ser interpretada en función del contexto social, producto de sensibilidades y creencias colectivas, de la religiosidad popular, y como construcción ideológica, es decir, forjada por un discurso, una narración de miembros de la institución eclesiástica o laicos eruditos. La historiografía nos ofrece una amalgama de ambas.

Las historias generales, locales y eclesiásticas trataron cuatro temas claves en los que lograron conjugar objetivos religiosos bien definidos: fomentar el desarrollo de la veneración y la devoción a la Virgen y a los santos, jerarquizar a las ciudades andaluzas y a sus entornos rurales demostrando la sacralización de sus distintos espacios, manifestar «orgullo patrio» al presentar los méritos de las ciudades a través de la «presencia» de la Virgen y sus «más ilustres hijos y ciudadanos»: los santos.

Imágenes y reliquias santas constituían los «grandes tesoros y la principal riqueza de las ciudades». Esos «regalos divinos» las engrandecían, ennoblecían y bendecían. Se explica así las extensas referencias al «coleccionismo» y posesión de sus catedrales, Iglesias, conventos y monasterios; los numerosos relatos sobre hallazgos o sobre traslatio y posterior recuperación por parte de las comunidades andaluzas de sus «santos patrones, defensores y protectores».

En las obras analizadas hubo un interés especial por determinar la localización de estos «lugares privilegiados» a raíz de la creencia de la permanente «presencia de los santos». De ahí que el recorrido o itinerario que siguieron los santos y la presentación de los lugares píos con los que estuvieron en contacto, sepulcros, catedrales, Iglesias, monasterios, conventos, calles, plazas, puertas, murallas, alcázares, casas, ríos, fuentes de agua, fueran un modo eficaz para que las ciudades andaluzas adquirieran relevancia en el mapa de las devociones religiosas de España. De este modo, la sacralización suponía que los lugares o espacios implicados adquirieran otro significado, una valoración especial por parte de los cristianos que se imponía sobre cualquier otra función o connotación que haya tenido antes, señalizándose, marcándose con cruces, santuarios, Iglesias y ermitas. La misma topo-

${ }^{69}$ RoA, Martín, Écija sus santos, su antigüedad eclesiástica y seglar, Sevilla, 1629, cap. II., 64v y cap. II., $67 \mathrm{v}$ y 68 .

Hispania Sacra, LXII

126, julio-diciembre 2010, 457-489, ISSN: 0018-215-X 
grafía de las ciudades andaluzas mostraba que los santos, sus reliquias e imágenes, fueron un componente fundamental de su paisaje rural y urbano y fijaban la existencia de numerosos lugares píos, centro de devociones de las comunidades.

Por otra parte, la legitimación de las reliquias fue también un medio idóneo para probar la sacralización de los lugares. Las categorías de reliquias incidieron en las categorías de «lugares santos», reforzando sobre todo el prestigio de las ciudades que poseían reliquias corporales, las más estimadas, las comunidades andaluzas podían correr el riesgo de salir perdiendo ya que muchas de estas habían sido trasladadas en la Edad Media para salvarlas y preservarlas de la dominación musulmana. Aunque se rescató de esos hechos aspectos positivos como el trasvase de devociones religiosas, la proyección e influencia de sus santos en otras ciudades de España, los discursos tendieron a resaltar que las ciudades andaluzas fueron espacios sacralizados por el número de reliquias corporales y representativas que poseían, por haber sido recuperadas o intercambiadas o por el descubrimiento milagroso de imágenes marianas. Desde este punto de vista, nunca perdieron la conexión y comunicación con sus santos.

Asimismo, las noticias sobre el poder milagroso que actuaba a través del contacto con las reliquias o las imágenes, o los lugares donde habían estado los santos, o algún elemento con el que tuvieron contacto, permitió exaltar las excelencias de los centros cultuales y los beneficios que obtenían los peregrinos que los visitaban. La cantidad variada de lugares con capacidad sobrenatural excedía al control eclesiástico. No estaba sólo en las tumbas de las Iglesias, conventos y monasterios, sino también en las creencias y las sensibilidades colectivas que los pusieron en distintos espacios de las ciudades.

Por último, las apariciones de los santos suponían un contacto directo entre los fieles y lo sagrado, entre el cielo y la tierra. En la Edad Media la intercesión de los santos los hizo héroes libertadores y salvadores. En la Edad Moderna, bajo el control eclesiástico, las apariciones se produjeron para legitimar reliquias santas, para avalar la dignidad de las instituciones eclesiásticas, que recibían anuncios celestiales, y recordar y encauzar a la comunidad en los deberes cristianos.

Aunque en nuestro análisis, muchas de las actitudes religiosas de los andaluces hacia los santos de sus ciudades fueron una continuación de prácticas arraigadas, se ha podido constatar que fueron actualizadas o reelaboradas en función de las circunstancias. De las fuentes se desprende que las ciudades permanentemente hicieron hincapié en mostrarse como los principales centros de la geografía de la santidad hispana. Así los santos asumían un papel histórico de primer orden, no sólo habían hecho triunfar el cristianismo en las ciudades, sino que las habían situado en la Historia Sagrada, argumento fundamental del orgullo urbano y ciudadano. Por tanto, prueba suficiente de que estos sentimientos localistas guiaban las intenciones, es la afirmación de la sacralidad totalizadora que proclamaban las ciudades. 